УДК 94:341.485(=163.41)(497.5)"1941/1942"(093.2)

$272-767(=163.41)(497.5) " 1941 / 1942 "(093.2)$

Dr Filip ŠKILJAN

\title{
PREVERAVANJE SRBA NA PODRUČJU SJEVEROZAPADNE HRVATSKE 1941. I 1942. GODINE ${ }^{1}$
}

\begin{abstract}
Apstrakt: Autor u radu donosi, na temelju arhivske građe iz Hrvatskog državnog arhiva, Arhiva Republike Slovenije, Državnog arhiva u Zagrebu i Nadbiskupskog arhiva u Zagrebu te dostupne literature, informacije o prekrštavanju Srba na području sjeverozapadne Hrvatske (Banija, Kordun, Moslavina, bjelovarski kraj, Podravina, Zagreb) 1941. i 1942. godine. Pravoslavni Srbi su pristajali na prekrštavanje zato da bi sačuvali svoje živote $i$ svoju imovinu, odnosno zato da ne bi bili prisilno iseljeni u Srbiju. U navedenom razdoblju od oko 250.000 Srba koji su živjeli na području sjeverozapadne Hrvatske njih najmanje 50.000 bilo je prekršteno. Nakon lipnja 1942, odnosno nakon uspostave Hrvatske pravoslavne crkve, masovno prekrštavanje uglavnom je prestalo. Međutim, ni pravoslavno stanovništvo koje je prekršteno nije uvijek uspjelo izbjeći prisilna iseljavanja, interniranja i stradavanja u masovnim pogromima.
\end{abstract}

Ključne reči: NDH, Srbi, nasilno preveravanje, ustaše, zakonodavstvo, propaganda

1 U historiografiji su se za promjenu konfesije Srba u Nezavisnoj Državi Hrvatskoj i njihovo uvođenje u rimokatoličku ili grkokatoličku vjeroispovijest dosad upotrebljavali različiti izrazi. Pored termina "pokrštavanje", koji je potpuno pogrešan jer su pravoslavni Srbi već jednom kršteni, najčešće su se koristili pojmovi "katoličenje", "prevjeravanje" te "vjerski prijelaz" i "konverzija". Prvi je pojam otvoreno tendenciozan i opterećen povijesnim talogom (misionarska katolizacija pagana), drugi obuhvaća svaku promjenu religije i vjere (ne radi distinkciju između "pokrštavanja" npr. Židova i "prekrštavanja" npr. Srba), a posljednja dva su koristile same ustaše i rimokatolički/grkokatolički kler i oni čin odreknuća dotadašnje, pravoslavne konfesije kroz inicijacijski čin uvođenja u katoličku konfesiju svode na politički neutralan, tehnički termin bez konotacija. Termin "vjerski prijelaz" osim toga implicira dobrovoljnost i neprisilnost, što za najveći broj odreknuća stare vjere Srba u NDH nikako ne bi mogli biti realni atributi, posebno ne za kolektivna prekrštavanja. Uz to, prekrštavanje nije bilo autonoman čin usklađen sa savješću pojedinca kojim se on iskreno, svjetonazorno i kognitivno usklađuje, nego iznuđen, dubiozan, ritualan čin uz posredovanje, što termini "vjerski prijelaz" i "konverzija" demagoški i obranaški prikrivaju. Termin "prekrštavanje", osim što je i kolokvijalno uobičajen, označava točno ono što se događalo Srbima u NDH u Drugom svjetskom ratu: implicira i genocidnu namjeru i spregu crkve i režima. Bez obzira na činjenicu da je "prekrštavanje" bilo "zamjenska" i "blaža" sudbina u odnosu na fizičko istrebljenje, bilo je ono genocidna poluga, nečasna praksa s časnim izuzecima. 


\section{Zakonski okviri i propaganda}

Ustaše u praksi nisu mogli pronaći zbirnu etničku/rasnu definiciju za pravoslavnu manjinu u NDH, pa su in definirali na temelju vjerske opredijeljenosti. Stoga je kao prvu instituciju koja je okupljala pravoslavne u NDH trebalo uništiti Srpsku pravoslavnu crkvu - glavni rasadnik srpskog identiteta u NDH. ${ }^{2}$ Jedan od oblika uništavanja utjecaja Srpske pravoslavne crkve bio je protjerivanje i prisilno iseljavanje pravoslavnih svećenika, što je u većini slučajeva provedeno početkom srpnja 1941. godine. ${ }^{3}$

Drugi oblik razaranja institucije Srpske pravoslavne crkve u NDH bilo je prekrštavanje pravoslavnog srpskog stanovništva, odnosno "prijelazi" s pravoslavne na rimokatoličku i grkokatoličku vjeroispovijest. Već 3. svibnja 1941, dakle svega tri tjedna nakon uspostave $\mathrm{NDH}$, poglavnik dr Ante Pavelić donio je Zakonsku odredbu o prijelazu s jedne vjere na drugu ${ }^{4}$ kojom se određenim kategorijama srpskog stanovništva u NDH omogućava zakonski "prijelaz" na rimokatoličku vjeru. Srbima, dakle, ukoliko nisu željeli da se isele ili da stradaju u nekom od pogroma, nije preostajalo drugo nego da se prekrste. ${ }^{5}$ Ova zakonska odredba omogućila je ustaškoj vlasti da se stavi iznad Rimokatoličke crkve, što je vidljivo iz člana u kojem stoji da je za valjanost prijelaza potrebno da stranka koja mijenja vjeru podnese pismenu prijavu prvoj instanci upravne vlasti (kotarskoj oblasti, odnosno gradskom poglavarstvu) o svojoj odluci i da dobije potvrdu o toj svojoj prijavi. ${ }^{6}$ Vrlo brzo nakon donošenja Zakonske odredbe o prijelazu s jedne vjere na drugu, 15 . svibnja 1941, Rimokatolička crkva šalje Okružnicu. ${ }^{7}$ U Okružnici stoji da se pristup u Rimokatoličku crkvu treba dopustiti samo onim osobama za koje postoji osvjedočenje da to žele učiniti "iskreno i s uvjerenjem o istinitosti naše svete vjere i o njenoj potrebi za spas duše". Naime, Rimokatolička crkva je na taj način željela izbjeći da razlozi "prelaženja" s jedne vjeroispovijesti na drugu budu egzistencijalne prirode, odnosno da budu primarno vezani za spašavanje života, imanja ili posla, što je gotovo redovito i bio slučaj. U okružnici je također stajalo da je potrebno da "prijelaznici" budu dobro poučeni vjerskim istinama, da ne žive u divljem braku i da djecu također "prevedu" na rimokatoličku vjeroispovijest. Ubrzo

2 Nevenko Bartulin, "Ideologija nacije i rase: ustaški režim i politika prema Srbima u Nezavisnoj Državi Hrvatskoj 1941. - 1945.", Radovi Zavoda za hrvatsku povijest, vol. 39 (2007), str. 228-229.

3 Jedan veliki broj pravoslavnih svećenika stradao je u pogromima koji su uglavnom uslijedili nakon iseljavanja ili su se odvijali istovremeno. (Vidjeti u: Veljko Đ. Đurić, Ustaše i pravoslavlje, Beograd, 1989, str. 106-117; Spomenica pravoslavnog sveštenstva žrtava fašističkog terora, Beograd 1960).

$4 \quad$ Narodne novine, 4. svibnja 1941.

5 Marco Aurelio Rivelli, Nadbiskup genocida, Nikšić, 1999, str. 40.

$6 \quad$ Narodne novine, 4. svibnja 1941.

$7 \quad$ Katolički list, br. 19, 15. svibnja 1941. 
nakon ove okružnice vidljivo je iz dopisa od 14. srpnja 1941. godine da je intencija ustaških vlasti da spriječe da pravoslavna inteligencija (svećenici, učitelji, trgovci, obrtnici i bogatiji seljaci) "prijeđu" na rimokatoličku vjeroispovijest. ${ }^{8}$ Iz dopisa je vidljivo i da se ustaške vlasti protive prekrštavanju na grkokatoličku vjeroispovijest, što je bio slučaj posebno u sjevernim dijelovima Hrvatske, odnosno u krajevima gdje je Križevačka biskupija imala dijecezansku nadležnost. Pročelnik Odjela za bogoštovlje A. Glavaš obavještava biskupske ordinarijate NDH o toj odluci Ministarstva bogoštovlja i pravosuđa. Po uputi nadbiskupa Stepinca, Josip Lach, generalni vikar, odgovara na ovaj dopis Ministarstva pravosuđa i bogoštovlja pismom u kojem stoji da se crkvene vlasti slažu s time da treba biti na oprezu oko prekrštavanja inteligencije, ali iz kojeg se vidi i da Stepinac smatra da ne treba a priori zabraniti bilo kakvu mogućnost prekrštavanja inteligencije na rimokatoličku vjeroispovijest, posebno ne braniti "prijelaze na grkokatoličku vjeroispovijest". ${ }^{9}$ Stepinac isto tako upućuje svoje svećenstvo da kada im dođu osobe "židovske ili pravoslavne vjeroispovijesti, koje se nalaze u smrtnoj opasnosti, pa zažele konvertirati na katolicizam, primite ih, da spasite ljudske živote. Ne zahtjevajte od njih nikakvo specijalno vjersko znanje, jer pravoslavni su kršćani kao i mi, a židovska je vjera ona, iz koje kršćanstvo vuče svoje korijene. Uloga i zadaća kršćana u prvom je redu spasiti ljude. Kada prođe ovo vrijeme ludila i divljaštva, ostat će u našoj Crkvi oni, koji budu konvertirali zbog uvjerenja, dok će se ostali, kada opasnost prođe, vratiti u svoje". ${ }^{10}$ Krajem srpnja 1941. Državno ravnateljstvo za gospodarsku ponovu piše okružnicu iz koje je ponovno vidljivo da je želja hrvatske vlade da "grko-istočni ne prelaze na grkokatolički obred osim u onim grkokatoličkim župama, koje su već osnovane i u kojima ima grko-istočnjaka". ${ }^{11}$ U Okružnici također stoji da pravoslavni moraju imati potvrde o čestitosti koje su izdavala kotarska i općinska poglavarstva u dogovoru s ustaškim logorima. Na taj način je ustaška vlast mogla uskratiti bilo kome prekrštavanje na rimokatoličku vjeroispovijest ukoliko su smatrali da dotični to nije zaslužio. Osim toga, upute su vrijedile za čitavo područje NDH osim za župe Gora te Krbava i Psat, gdje je ustanak krajem srpnja već bio buknuo, pa su ustaške mjere protiv Srba bile drugačije. I pojedini župnici na području sjeverozapadne Hrvatske bunili su se protiv toga da ustaški logori sami odlučuju kome će se dozvoliti prekrštavanje na rimoka-

8 Veljko Đ. Đurić, Prekrštavanje Srba u Nezavisnoj Državi Hrvatskoj, Prilozi za istoriju verskog genocida, Beograd, 1991, str. 41-42.

9 Sima Simić, Prekrštavanje Srba za vreme Drugog svetskog rata, Titograd, 1958, str. 63-64.

10 Jure Krišto, Sukob simbola, Politika vjere i ideologije u Nezavisnoj Državi Hrvatskoj, Zagreb, 2001, str. 189.

11 V. Đ. Đurić, Prekrštavanje Srba u Nezavisnoj Državi Hrvatskoj, Prilozi za istoriju verskog genocida, Beograd, 1991, str. 45-46. 
toličku vjeroispovijest, a kome neće. ${ }^{12}$ Tako su župnici iz Grubišnog Polja, Velikog Grđevca i Srijemskih Karlovaca uputili dopis poglavniku dr Anti Paveliću u srpnju 1941. u kojem traže da se "inteligenciji, obrtnicima, trgovcima i istaknutim seljacima koji su bili vodeće ličnosti u velikosrpskim strankama i terorističkim organizacijama uskrati vjerski prijelaz. Izuzetak za navedene bilo bi jedino kod mješovitih brakova i izuzetnih pojedinaca koji su se uvijek korektno vladali prema Hrvatima, te odobravali borbu hrvatskog naroda protiv tiranije beogradske."13

Da su lokalne vlasti izigravale upute i zakonske odredbe koje su dobivale od državnih vlasti, vidljivo je iz dopisa nadstojnika vjerskog odsjeka Dionizija Juričeva u Državnom ravnateljstvu za ponovu. On je, naime, 16. prosinca 1941. poslao dopis Državnom ravnateljstvu za javni red i sigurnost i ustaškim stožerima u svim velikim župama, u kojem je stajalo da je potrebno sve one "koji su najavili ili izvršili prijelaz iz grčkoistočne vjere najustaškije zaštititi, te im se ima osigurati kako osobna, tako i imovinska zaštita i sigurnost kao i svim ostalim državljanima Nezavisne Države Hrvatske". Nadstojnik vjerskog odsjeka svjestan je da se usprkos prekrštavanju na rimokatoličku vjeroispovijest u nekadašnjim pravoslavnim selima vrše zločini, hapšenja i nasilja. Nadstojniku Juričevu je iznimno smetalo što je "primjećeno, da neki od područnih vlasti i organa ometaju vjerski prielaz grčkoistočnjaka na rimokatoličku vjeroispoviest, te taj prielaz ismijavaju, omalovažavaju pa čak nastoje da silu upotriebe da prielaz sprieče", pa moli da to prestane. Osim toga primijetio je da se u nekim krajevima ide tako daleko da se izjavljuje da "šta trebaju vlasi prelazit treba ih sve pobit itd." ${ }^{14}$ Isto tako i predstojnik odjela bogoštovlja Ministarstva pravosuđa i bogoštovlja Radoslav Glavaš inzistira na tome da "oni koji su prešli na katolicizam treba da osjete da su dobili neku zaštitu u pogledu odpuštanja i selenja". ${ }^{15}$

Osim brojnih okružnica i zakonskih odredaba, i u dnevnom i tjednom tisku stvarana je propaganda o hrvatstvu bosanskohercegovačkih i hrvatskih pravoslavaca. Najčešći tipovi članaka bili su vezani upravo za povijesnu istinu o pravoslavnom pučanstvu u NDH. Putem novina željelo se prikazati hrvatske i bosanskohercegovačke pravoslavce Hrvatima koji su nekada bili rimokatoličke vjeroispovijesti, a pravoslavlje su prihvatili usljed povijesnih okolnosti. Takvu je tezu postavio i Jere Jareb u listu Ustaša. On piše kako je "ogromna

12 O tome kako se crkva sukobljavala s državom u vezi s prekrštavanjima vidjeti u: Jure Krišto, Sukob simbola, Politika vjere i ideologije u Nezavisnoj Državi Hrvatskoj, Zagreb, 2001, str. 172-184.

13 Hrvatski državni arhiv (dalje HDA), Ministarstvo pravosuđa i bogoštovlja Nezavisne države Hrvatske (dalje MPB NDH), Odjel bogoštovlja, kutija 5, 533-B-1941.

14 HDA, Državno ravnateljstvo za ponovu, Vjerski odsjek, kutija 584, 603/1941.

15 HDA, Ministarstvo unutarnjih poslova NDH (dalje MUP NDH), I-C, kutija 57, 4123/41. Citirano prema: J. Krišto, Sukob simbola, Politika vjere $i$ ideologije $u$ Nezavisnoj Državi Hrvatskoj, Zagreb, 2001, str. 185. 
većina grkoistočnjaka na našem teritoriju zapravo čistog hrvatskog i katoličkog porijekla". "Svi stanovnici istočne Hercegovine, danas skoro isključivo grko-istočnjaci, bijahu katolici, a da ne govorimo o ostaloj Bosni." Jareb Srbima priznaje jedino pravoslavne u Srijemu, "i to ne sve". Tvrdi da je srpska propaganda od polovice 19. stoljeća inzistirala na tome da su svi pravoslavci Srbi i da danas "grko-istočnjaci konačno uviđaju da je ta vjera bila kriva njihovom nacionalnom nesnalaženju i stoga se opet vraćaju bilo vjeri svojih otaca, bilo vjeri ogromne većine svog hrvatskog naroda". ${ }^{16}$ Ustaše su željeli prikazati da su Srbi u Hrvatskoj i Bosni i Hercegovini pod pritiskom Osmanlija primili pravoslavlje i da se ovdje uopće ne radi o Srbima, nego o starom hrvatskom stanovništvu koje je prihvatilo pravoslavlje nadajući se boljem položaju pod turskom vladavinom. Željelo se zapravo prikazati da je prekrštavanje pravoslavnog stanovništva na rimokatoličku vjeroispovijest samo vraćanje "vjeri otaca". Tako je i sam Pavelić u tjedniku Neue Ordnung izjavio: "Što se tiče Srba tu je nastalo miješanje pojmova. Pravih Srba u Hrvatskoj nema mnogo. Većim dijelom su to Hrvati srpsko-pravoslavne vjere i Vlasi. Ovo će pitanje biti riješeno na najbolji, najzgodniji način. Sporazumno s njemačkim vlastima poslat će se 250.000 Srba u Srbiju, dok će drugi moći ostati ovdje. Ne će im se praviti nikakvih poteškoća." Pavelić je to opravdavao činjenicom da se među Srbima javlja pokret koji ima za cilj da se oni "vrate hrvatstvu i prijeđu na rimokatoličku vjeru". ${ }^{17}$

Ustaški dužnosnici širili su spomenutu propagandu i na velikim ustaškim skupštinama koje su održavane diljem NDH. Radilo se, dakle, u prvom redu o mnogobrojnim organiziranim političkim skupovima širom NDH na kojima su istupali pojedini visoki ustaški funkcionari koji su tumačili i propagirali ciljeve novouspostavljene NDH i ustaškog pokreta. Na tim je skupštinama došlo do osobitog širenja govora mržnje, a prema zapažanju Fikrete Jelić-Butić vidljiva su tri elementa: Srbima nema mjesta u NDH, odnosno oni se moraju vratiti odakle su i došli - u Srbiju, Srbi su oduvijek željeli loše Hrvatima i srpsko pitanje u Hrvatskoj treba efikasno riješiti, a ustaše znaju i kako. ${ }^{18}$

Eksterminacija kao potpuno i nemilosrdno uništenje, istrebljenje, iskorjenjivanje i zatiranje, najtočniji je pojam za imenovanje genocidne politike koju je ustaška Nezavisna Država Hrvatska u četiri godine svog postojanja provodila prema Srbima kao narodu. Pojam

16 Ustaša, br. 18, 30. studeni 1941, str. 3. Na sličan način piše i Krunoslav Draganović u knjizi Katolička crkva u Bosni i Hercegovini nekad i danas, gdje ističe kako je Bosna nekada bila u potpunosti rimokatolička zemlja te da je tek srpskom i turskom akcijom postala djelomično pravoslavna, odnosno da je tada naseljen određen broj pravoslavnih koji su istisnuli rimokatoličko stanovništvo. (HDA, Ministarstvo unutarnjih poslova Socijalističke Republike Hrvatske (dalje MUP $\mathrm{SRH}), 013.0 .3$, elaborat nepoznatog autora pod pseudonimom Dizdar, Ustaštvo i $\mathrm{NDH}, 56)$

17 Neue Ordnung, 24. kolovoza 1941.

18 Fikreta Jelić-Butić, Ustaše i NDH, Zagreb, 1978, str. 163-164. 
je gotovo istoznačan s holokaustom Židova u Trećem Reichu i kvislinškim europskim državama, a po okrutnosti i sistematičnosti ravan mu je još jedino genocid nad Romima. Tako trima pojmovima imenujemo istu sudbinu triju naroda koju im je, kao nearijskima, rasistička naci-fašistička ideologija namjenila, a u velikoj mjeri i ostvarila, tridesetih i ranih četrdesetih godina XX stoljeća.

Zatiranje nekog naroda ideološka je strategija i planirana praksa koja podrazumijeva razrađenu metodologiju, sinergijsku koncentraciju i kontinuitet, a frontalno zahvaća sve aspekte bića naroda koji se uništava: kulturni i vjerski identitet, pisanu povijest i svaki materijalni trag te samu biološku egzistenciju onih koji mu pripadaju. Provodi se svim oblicima demagogije, mistifikacije, falsificiranja i laži. Prati ga zakonodavna i sudska praksa, medijska demonizacija i dnevnopolitičko šikaniranje (zabrane identitetnih oznaka, izrade raznih spiskova pripadnika, proizvodnja stida zbog pripadnosti, odgoj vlastite mladeži za mržnju) te represija državnog aparata (uskraćivanje prava jednakosti pred zakonom, otkazi, uzurpacije imovine, zatvaranja, progoni, organizirana prisilna iseljavanja, ubojstva, masovne likvidacije). Vrhunac je kad se svi kriteriji sliju u jedan - u samo ime naroda.

Prva prekrštavanja na području NDH bila su obavljena i prije donošenja ovih zakonskih odredbi i okružnica. Doduše, radilo se u najvećem broju slučajeva o pojedinačnom prekrštavanju koje je učinjeno zbog straha za vlastiti život. U ovom članku interes će biti poklonjen upravo prekrštavanjima koja su obavljena od ljeta 1941. do kasnog proljeća 1942. godine na području Zagreba, Banije, Korduna, Podravine, Moslavine i bjelovarskog kraja. Ova nam je zona bila posebno zanimljiva zbog velikog broja srpskog pravoslavnog stanovništva koje je živjelo na tome području, zbog prekrštavanja na grkokatoličku i rimokatoličku vjeroispovijest i zbog činjenice što je sjeverni dio ove zone (Podravina, Moslavina, Bjelovarsko prigorje, Hrvatsko zagorje i Kalničko prigorje) uglavnom bio mirno područje gdje se u 1941. i 1942. nisu odvijale vojne operacije, dok je južni dio teritorija (Gorski kotar, Banija i Kordun) predstavljao jedan od centara ustanka na području NDH. U kasno proljeće 1942. uspostavljena je Hrvatska pravoslavna crkva, čime se značajno smanjio broj prekrštavanja, odnosno ona više nisu predstavljala masovnu pojavu na području NDH.

\section{Geografski okviri}

Promatrajući navedeno područje, ustanovljeno je da je srpsko pravoslavno stanovništvo živjelo u ovim zonama u oblasti Podravine (u nekoliko sela u ludbreškoj Podravini, u bilogorskim selima na području koprivničkog kotara i u jednom selu nedaleko Đurđevca), u dijelovima Moslavine (u više sela na području Garešnice, nekoliko sela u okolici Čazme, u manjem broju sela oko Kutine i Ivanić Gra- 
da), na većem dijelu Banije (Petrinja, Glina, Dvor, Sisak, Kostajnica), na većem dijelu Korduna (Vrginmost, Vojnić, Karlovac, Slunj i Duga Resa), na području bjelovarsko-križevačke zone (u više sela kotareva Križevci i Bjelovar) te u okolici Vrbovskog i Ogulina. U tekstu će se pokušati doći do broja prekrštenih u određenim zonama u navedenom periodu i do okolnosti oko vjerskih "prijelaza" na spomenutom području.

\section{Ustaški progoni u sjeverozapadnoj Hrvatskoj}

Odmah nakon uspostave NDH ustaše su počeli progoniti Srbe. Prvi progoni Srba započeli su u Gudovcu nedaleko Bjelovara, gdje je krajem travnja 1941. ubijeno oko 200 Srba. ${ }^{19}$ Nedugo potom, početkom svibnja 1941, u selu Blagaj u kotaru Slunj ubijeno je blizu četiri stotine srpskih muškaraca iz Veljuna i okolice, ${ }^{20}$ a svega nekoliko dana poslije toga, 13. svibnja 1941, počinjen je pokolj u okolici Gline nedaleko sela Prekopa, gdje je ubijeno između 300 i 400 Srba. ${ }^{21}$ Svi ovi pokolji, koji su se zbili na području koje je centar istraživanja u ovome radu, imali su za funkciju zaplašivanje srpskog pravoslavnog stanovništva, koje je nakon toga trebalo ili izbjeći, odnosno prisilno iseliti u Srbiju ili pristati na prekrštavanje. Ta tri zločina (Gudovac, Veljun i Glina) bila su tek uvod u naredne događaje koji će se također odigrati na spomenutom terenu. Nakon dizanja ustanka na području Banije i Korduna u srpnju 1941. godine uslijedilo je masovno prisilno iseljavanje Srba koje je djelomično uspješno provedeno na području Petrinje, Bjelovara, Grubišnog Polja, Garešnice, Ludbrega, Koprivnice, Čazme i Zagreba, dok na ostalom dijelu sjeverozapadne Hrvatske ta prisilna iseljavanja nisu bila značajnijeg opsega. ${ }^{22}$ Istovremeno s

19 O zločinu u Gudovcu vidjeti u: Slavko Goldstein, 1941. Godina koja se vraća, Zagreb, 2007, str. 91-96; Miloš Bjelovitić, Ilija Jarić, Gudovac 1941. - Da se ne zaboravi, Banja Luka, 2002; Stjepan Blažeković, "Živi svjedok gudovačke tragedije", Bjelovarski zbornik 1, Bjelovar, 1989, str. 60-73; Željko Karaula, "Slučaj Gudovac 28. travnja 1941", Radovi Zavoda za hrvatsku povijest, sv. 39 (2007), str. 197-208; Ivo Goldstein, Hrvatska 1918. - 2008., Zagreb, 2008, str. 264.

20 O veljunskom zločinu vidjeti u: Dušan Korać, Kordun i Banija u narodnooslobodilačkoj borbi i socijalističkoj revoluciji, Zagreb, 1986, str. 107-108; S. Goldstein, 1941. Godina koja se vraća, Zagreb, 2007, str. 97-104; I. Goldstein, Hrvatska 1918.2008., Zagreb, 2008, str. 265; Ivan Strižić, Žrtvoslov slunjskoga kotara, SlunjZagreb, 2005, str. 95-123.

21 O glinskom majskom zločinu vidjeti u: Čedomir Višnjić, Branko Vujasinović, Đuro Roksandić, Glina 13. maja 1941, Zagreb, 2011; Đuro Roksandić, "Ustaški zločini u glinskom kotaru od 1941. do 1945", Glina - Glinski kraj kroz stoljeća, Glina, 1988, str. 285-289.

22 O iseljavanjima Srba i useljavanjima Slovenaca vidjeti u: Fikreta Jelić-Butić, Ustaše i Nezavisna Država Hrvatska 1941.-1945., Zagreb, 1978, str. 167-171; Andrija Ljubomir Lisac, "Deportacije Srba iz Hrvatske 1941. godine", Historijski zbornik, 1-4 (1956), str. 125-145; Ivo Goldstein, "Iseljavanje Srba i useljavanje Slovenaca u NDH 1941. godine", Med srednjo Evropo in Sredozemljem: Vojetov 
prisilnim iseljavanjima, počinjeni su novi zločini koji su bili karaktera odmazde. Tako su u tome periodu počinjeni zločini u Banskom Grabovcu na petrinjskom području, gdje su likvidirani srpski seljaci sa glinskog i petrinjskog područja zbog dizanja ustanka na Baniji i gdje je stradalo najmanje 500 osoba, prema istraživanjima Slavka Goldsteina. ${ }^{23}$ Neposredno nakon ovoga slučaja dogodio se i veliki pokolj Srba u glinskoj crkvi (postoje sporenja o broju ubijenih). ${ }^{24}$ Sve ove ustaške akcije poticale su lokalno srpsko stanovništvo na bijeg od kuća i dizanje ustanka, odnosno sukobljavanje s ustaškom vlašću. Dakako, bilo je mnogo Srba koji su išli linijom manjeg otpora smatrajući da je najpametnije slušati bilo koju vlast ma kakva ona bila, te da će se represivne mjere s vremenom smiriti, odnosno da će zaobići njihovo selo ukoliko se oni ne budu bunili.

\section{Prisilno iseljavanje pravoslavnih svećenika}

Prvi koji su prisilno iseljeni bili su pravoslavni svećenici. Uglavnom nisu bili spremni na pokrštavanje - tek pokoji Rus ili Ukrajinac se odlučivao za prekrštavanje na rimokatoličku ili grkokatoličku vjeroispovijest. Prema ustaškim evidencijama, s područja NDH prisilno je iseljeno 327 pravoslavnih svećenika preko logora za iseljenike (preko logora u Capragu ili preko logora u Požegi). ${ }^{25}$ Broj prisilno iseljenih svećenika, igumana, kateheta ili crkvenih činovnika, koji su prisilno

zbornik, S. Jerše (ur.), Ljubljana, 2006, str. 595-605; Slobodan D. Milošević, Izbeglice i preseljenici na teritoriji okupirane Jugoslavije, Beograd, 1981; Miodrag Bjelić, Sabirni ustaški logor u Slavonskoj Požegi 1941. godine, Beograd, 2008; Marica Karakaš-Obradov, "Migracije srpskog stanovništva na području Nezavisne Države Hrvatske", Časopis za suvremenu povijest, br. 3 (2011), str. 801-826; Tone Ferenc, Nacistička politika denacionalizacije u Sloveniji u godinama od 1941. do 1945, Ljubljana-Beograd, 1979, str. 232-240; Filip Škiljan, "Prisilno iseljavanje Srba iz Moslavine 1941. godine", Historijski zbornik, 1 (2012), str. 149-168; F. Škiljan, "Organizirano masovno prisilno iseljavanje Srba iz Hrvatske 1941. godine", Stanovništvo, br. 2 (2012), str. 1-34.

23 O zločinu u Grabovcu vidjeti u: S. Goldstein, 1941. Godina koja se vraća, Zagreb, 2007, str. 293-297; Nikola Živković, Petar Kačavenda, Srbi u Nezavisnoj Državi Hrvatskoj, Beograd, 1998, str. 182-184; Đ. Roksandić, "Ustaški zločini u glinskom kotaru od 1941. do 1945", Glina - Glinski kraj kroz stoljeća, Glina, 1988, str. 290; HDA, Zemaljska komisija za utvrđivanje zločina okupatora i njihovih pomagača - Zh, kutija 298, 17627-17721, HDA, ZKRZ-Zh, kutija 137, 319/45 i HDA, ZKRZZH, kutija 690.

24 O glinskom zločinu u kolovozu vidjeti u: Đ. Roksandić, "Ustaški zločini u glinskom kotaru od 1941. do 1945. godine", Glina - glinski kraj kroz stoljeća, Glina, 1988, str. 292-293; HDA, Zemaljska komisija za utvrđivanje zločina okuptaora i njihovih pomagača, kutija 150, 890/44; Tomislav Vuković, "Ustaški pokolj u pravoslavnoj crkvi u Glini - povijesni događaj ili mit", nastavak 4, Glas koncila. (www.glaskoncila.hr); D. Ćubrić, M. Krković, Stradanje Srba u pravoslavnoj crkvi u Glini i rušenje spomenika, Beograd, 2005; Đuro Aralica, Ustaški pokolji Srba u glinskoj crkvi, Beograd, 2010.

25 HDA, Državno ravnateljstvo za ponovu, Srpski odsjek, kutija 473, 11063/41. 
iseljeni preko logora ili samostalno, a koje su ustaške vlasti uspjele popisati, iznosi 364 imena i prezimena. Glavnina prisilnog iseljavanja pravoslavnih svećenika obavljena su u prvoj polovici srpnja 1941, a manji broj je iseljen početkom kolovoza 1941. Nakon što su prisilno iseljeni pravoslavni svećenici, put prema prekrštavanju srpskog stanovništva bio je olakšan.

\section{Sakralne građevine Pravoslavne crkve i njihova sudbina}

Kao simbol pravoslavlja na ovim prostorima bile su relativno brojne pravoslavne parohijalne crkve i filijalni hramovi. Njihova je sudbina bila vrlo različita, ovisno o razini indoktrinacije lokalnog rimokatoličkog župnika, ustaškog tabornika ili okolnog hrvatskog stanovništva.

Pojedine pravoslavne kapele i crkve rušene su da bi se sagradili objekti koji bi koristili široj zajednici. Tako je srušena parohijalna crkva u selu Crkveni Bok nedaleko Hrvatske Kostajnice, a njezin je materijal bio predviđen za izgradnju rimokatoličke župne crkve koja nikada nije podignuta. ${ }^{26}$ Slično je bilo i s kapelom u Graberju koju su ustaške vlasti počele rušiti već 1941. Lokalni rimokatolički župnik iz Ivanić Kloštra, Pišpek, intervenirao je da se spriječi rušenje ove bogomolje. Njemu se, koliko je vidljivo iz dopisa, činilo da je skandalozno da se ruše vjerski objekti i shvaćao je da će to imati neugodne posljedice kod prekrštenih Srba iz ivanićgradskog kraja koji su posebno držali do ove crkve i njezinih zvona, za koja su smatrali da ih štite od tuče. Stoga je predlagao da se crkva pretvori u rimokatoličku bogomolju, a da se malobrojnim prekrštenim Srbima u njoj drži služba. Međutim, vlasti Velike župe Bilogora smatrale su da crkvu treba porušiti, ${ }^{27}$ a sličan je dopis uputio i kotarski predstojnik u Čazmi. On je, naime, putujući prema Ivanić Gradu zapazio na raskrsnici u Graberju "napola porušenu grčkoistočnu crkvu. Ista je bez gornjeg diela tornja i bez krova, cigla pobacana po tlu. Sve daje vrlo loš izgled. Stranci zastaju i slikaju istu, pa vjerojatno pišu kako mi Hrvati rušimo crkve." 28 Načelnik nadalje moli da se crkva poruši do

26 HDA, MPB NDH, kutija 23, 6835-B-1941.

27 HDA, MPB NDH, kutija 29, 1864-B-1942. Na području bjelovarskog kraja tako su srušene crkve u Lasovcu, Orovcu i Ribnjački, na području kotara Grubišno Polje u Velikoj Dapčevici, na području kotara Karlovac u Sjeničaku, Gornjem Budačkom i Utinji, na području Kostajnice u Brđanima, Crkvenom Boku, Četvrtkovcu, Drljačama, Strmenu, Timarcima, Velikoj Gradusi, Šašu, Hrvatskoj Dubici, Hrvatskoj Kostajnici, Ćukuru, Utoliči, Živaji, Lovči i Kinjačkoj, na području Petrinje u Petrinji, Tremušnjaku i Velikom Šušnjaru, na području Gline u Bojni, Brezovom Polju, Glini, Hajtiću i Velikom Gradcu, na području Vrginmosta u Topuskom, Čemernici, Pješčanici, Slavskom Polju i Stipanu, na području Vojnića u Dunjaku i Širokoj Rijeci, a na području Slunja u Radovici.

28 HDA, MPB NDH, kutija 36, 3619-B-1942. Građa s crkve trebala je biti upotrijebljena za Ustaški dom u Graberju. 
kraja. Sličan je problem postojao i s pravoslavnom crkvom u Maloj Trešnjevici pokraj Đurđevca, za koju je Nadbiskupski duhovni stol u Zagrebu intervenirao da se ne ruši nego "preinači" u rimokatoličku kapelu. Na samom terenu 16. siječnja 1942. do spomenute crkve su došli djelatnici jednog građevnog poduzeća iz Suhopolja, dva oružnika i dvojica ustaša; oni su trebali crkvu do temelja srušiti, čemu su se usprotivili rimokatolici iz Male Trešnjevice. Nakon toga događaja intervenirao je rimokatolički župnik iz Kozarevca uputivši dopis na Nadbiskupski duhovni stol u Zagrebu. Crkva nije srušena. ${ }^{29}$ I druge objekte valjalo je prenamijeniti. Takav je slučaj bio s kapelom Svetog Petra u mjestu Ivanić Grad. Ondje je rimokatolički župni ured tražio da se kapela pretvori u obdanište za napuštenu djecu pod upravom časnih sestara. ${ }^{30}$ Objekt je srušen, vrlo vjerojatno tokom 1942. godine na zahtjev kotarske oblasti u Čazmi. ${ }^{31}$ Sakralni objekti pravoslavne crkve u NDH u mjestima u kojima su pravoslavni prekršteni trebali su biti preuređeni u rimokatoličke crkve. Tako se iz crkava trebao ukloniti ikonostas, odnosno postaviti provizorne oltare za služenje svete mise. Ukoliko se pravoslavna crkva iz nekog razloga ne bi mogla adaptirati u rimokatoličku, trebalo je za potrebe vjerske službe adaptirati školske prostorije u tome naselju. ${ }^{32}$ Mještani sela Trnovitički Popovac nedaleko Garešnice, rimokatoličke vjeroispovijesti, njih 96 zajedno s obiteljima, tražili su ustupanje pravoslavne crkve za potrebe rimokatolika i prekrštenih kojih je u to vrijeme bilo podosta u selu. ${ }^{33}$ Isti je slučaj bio i s rimokatolicima naselja Lipnica i Kolenica pokraj Vrbovca koji su tražili ustupanje nekadašnje pravoslavne crkve u Lipnici. Međutim, zbog prekrštavanja na grkokatoličku vjeroispovijest nekadašnjih 26 pravoslavnih obitelji (od ukupno 30 pravoslavnih obitelji) u Lipnici i zbog ustupanja ove crkve Grkokatoličkoj crkvi ovaj objekt nije mogao preći u vlasništvo rimokatolika. ${ }^{34}$ Ipak grkokatolički administrator Križevačke biskupije Janko Šimrak istaknuo je da je spreman "uvijek rimokatolicima ustupiti crkvu u Lipnici na korištenje". ${ }^{35}$ Žitelji rimokatoličke vjeroispovijesti Gornjih Sredica u sjevernom dijelu općine Kapela zatražili su početkom 1942. godine da im se prepusti pravoslavna kapela koja je postojala u njihovu mjestu. Budući da je većina mladića rimokatoličke vjeroispovijesti

29 HDA, MPB NDH, kutija 28, 1096-B-1942.

30 HDA, Državno ravnateljstvo za ponovu, vjerski odsjek, kutija 584, 8/1941. Iako je kapela dodijeljena za časne sestre, župni ured u Ivanić Gradu je tražio da se zemljište proda i da se zamijeni za neko drugo, povoljnije zemljište, budući da se ovo nalazilo na vrlo prometnom mjestu. (HDA, MPB NDH, kutija 39, 4598-B1942).

31 HDA, MPB NDH, kutija 43, 5706-B-1942.

32 Viktor Novak, Magnum crimen, Pola vijeka klerikalizma u Hrvatskoj, Beograd, 1986, str. 690.

33 HDA, MPB NDH, kutija 18, 5639-B-1941.

34 HDA, MPB NDH, kutija 40, 4902-B-1942.

35 HDA, MPB NDH, kutija 48, 8207-B-1942. 
bila na odluženju vojnog roka ili su bili mobilizirani, rimokatoličku kapelu selo nije moglo podići. Međutim, kako se slučaj dugo rješavao, u međuvremenu je uspostavljena Hrvatska pravoslavna crkva pa je njihova molba postala bespredmetna. ${ }^{36}$ Pojedine pravoslavne crkve nisu trebale biti predane grkokatolicima ili rimokatolicima, nego nekoj drugoj pravoslavnoj crkvi. Tako je Ministarstvo vanjskih poslova 24. srpnja 1941. poslalo dopis Ministarstvu pravosuđa i bogoštovlja u kojem zahtijeva da se srpska pravoslavna crkva u Zagrebu preda Rusima, odnosno ruskom svećeniku koji je obavljao službu umjesto izbjeglog srpskog svećenika. I Bugari i Rumunji u Zagrebu, kako stoji u dopisu, "sasvim sigurno ne bi željeli da se posluže pravoslavnom crkvom ukoliko bi ta crkva imala ikakve veze sa srpstvom". ${ }^{37}$

Iz svega spomenutog jasno je vidljivo da su pravoslavne crkve na području Zagrebačko-ljubljanske mitropolije i Gornjokarlovačke eparhije stradavale na najrazličitije načine. Prve su bile porušene na zahtjev ustaških vlasti, neke su bile znatno oštećene, dok su treće bile pretvorene u rimokatoličke ili grkokatoličke crkve. Nakon ljeta 1942. crkve koje nisu doživjele ovakvu sudbinu pretvorene su u Hrvatske pravoslavne crkve.

\section{Prekrštavanja po regijama}

Kordun (Slunj, Karlovac, Vojnić, Vrginmost) i Gorski kotar (Ogulin, Vrbovsko)

Kao što je već spomenuto, područje Korduna bilo je zona ratnih djelovanja od srpnja 1941. kada je na tome teritoriju započeo ustanak. Dakako, zbog toga je broj molbi za "prijelaz na rimokatoličku vjeroispovijest" u relativnim brojkama bio znatno manji negoli je to bio slučaj u krajevima oko Bjelovara, Križevaca, odnosno u Moslavini i Podravini.

Iz dokumenata sačuvanih u Hrvatskom državnom arhivu vidljivo je da je u kolovozu 1941. godine župnik iz Slunja Ivan Nikšić molio da se "grčko-istočne obitelji" iz Slunja i okolice koje su najavile "prijelaz na rimokatoličku vjeroispovijest" ne deportiraju u Srbiju, odnosno da se ostave kod svojih kuća jer je to želja ovdašnjih Hrvata. Nikšić ističe da taj dopis šalje zato da ne bude kasno, kao što je bilo kasno za Srbe iz Veljuna. ${ }^{38}$ Na području slunjskog kotara nije bilo puno slučajeva masovnih prekrštavanja, ali se ipak ističu prekrštavanja koja su učinjena na granici s Bosnom, u cetingradskom kraju i kraju oko Kordunskog Ljeskovca. Skupnu molbu za "prijelaz na rimokatoličku vjeroispovijest" podnijelo je selo Kordunski Ljeskovac uz rijeku Koranu uz bosansku granicu. Seljaci Kordunskog Ljeskovca obratili su

36 HDA, MPB NDH, kutija 69, 2027-B-1943.

37 HDA, MPB NDH, kutija 3, 5174/41.

38 HDA, MPB NDH, kutija 3, 51353/41. 
se osobno poglavniku dr Anti Paveliću tražeći mu da zaštiti njihove živote i živote njihovih obitelji, "pošto nam je danomice ugrožen i u opasnosti sa strane nediscipliniranih i samovoljnih elemenata, koji unose nemir i nespokojstvo u naše selo..." U pismu dalje nastavljaju da su spremni za "prijelaz na rimokatoličku vjeroispovijest" ukoliko im Pavelić zagarantira da se "nitko ne smije napadati, budući da je do tada već bilo odvođenja, zlostavljanja, ubijanja i pljačke, pa čak i nasilja nad nedužnim stanovnicima ovog kraja". U potpisu je stajalo 99 osoba koje su željele "prijeći na rimokatoličku vjeroispovijest" iz Kordunskog Ljeskovca. ${ }^{39} \mathrm{Na}$ cetingradskom području za prekrštavanje na rimokatoličku vjeroispovijest je do sredine studenog 1941. zamolilo 859 osoba, a već ih je bilo prekršteno 2.027. Sveukupan broj pravoslavnih na tom području iznosio je 4.728, što bi značilo da je do toga vremena već više od polovice njih najavilo prekrštavanje ili već bilo prekršteno na rimokatoličku vjeroispovijest. ${ }^{40}$ Čini se da je na tome području selo Begovo Brdo prevedeno na islam, ali je to selo prema pisanju Viktora Novaka čitavo likvidirano u ožujku $1942 .{ }^{41} \mathrm{Na}$ području općine Primišlje, u kojoj je relativno rano buknuo ustanak, od 6.909 pravoslavnih nitko nije prekršten na rimokatoličku vjeroispovijest, a veoma malen broj je i bio zainteresiran za prekrštavanje. Kao razlog slabom odazivu općinsko poglavarstvo u Primišlju ističe nemire u općini i "što nadolazeći lopovi iz pojedinih mjesta žiteljima sprečavaju prijelaz na rimokatoličku vjeru, pa se isti od njihove strane boje da ne stradaju". 42

$\mathrm{Na}$ nekim drugim dijelovima Korduna, poput općine $\mathrm{Vr}$ ginmost, gdje je bio 9.941 pravoslavni, svega je njih 194 do studenog 1941. prekršteno na rimokatoličku vjeroispovijest, dok ih se 856 "najavilo za prijelaz". ${ }^{43} \mathrm{U}$ vrginmošćanskom kraju jedino su pravoslavci iz sela Prkos u potpunosti prekršteni, prema iskazu Sime Dimovića, svećenika iz Sjeničaka, ${ }^{44}$ ali ta im činjenica nije pomogla budući da je gotovo čitavo selo pobijeno u prosincu iste godine. ${ }^{45}$ Na području općine Lasinja u kotaru Pisarovina, prije rata u kotaru Vrginmost, u koje je spadalo i selo Prkos, bilo je 1.047 pravoslavnih domaćinstava sa 5.784 žitelja. Od toga je do 23. rujna 1941. 787 obitelji, odnosno 3.798 osoba podnijelo "molbe za vjerski prijelaz" na rimokatoličku vjeru, dok 260 domaćinstava, odnosno 1.987 duša

39 HDA, MPB NDH, kutija 14, 4453-B-1941.

40 HDA, Državno ravnateljstvo za ponovu, vjerski odsjek, kutija 584, 167/1941.

41 V. Novak, Magnum crimen, Pola vijeka klerikalizma u Hrvatskoj, Beograd, 1986, str. 761.

42 HDA, Državno ravnateljstvo za ponovu, vjerski odsjek, kutija 584, 585/1941.

43 HDA, Državno ravnateljstvo za ponovu, vjerski odsjek, kutija 584, 313/1941.

44 V. Đ Đurić, Prekrštavanje Srba u Nezavisnoj Državi Hrvatskoj, Prilozi za istoriju genocida, Beograd, 1991, str. 184.

45 O tome događaju vidjeti podrobno u: Dušan Korać, Prkos u plamenu, Zagreb, 1989. i S. Goldstein, 1941. Godina koja se vraća, Zagreb, 2007, str. 344-398. 
nije podnijelo tu molbu. ${ }^{46}$ Veći broj seljaka iz Vrginmosta i okolice stradao je kada su početkom kolovoza na prevaru odvedeni u glinsku crkvu na prekrštavanje. U Vrginmostu je prema sjećanjima Branka Žutića "s okupljenim narodom izvedena tragična i nezapamćena lakrdija. (...) Ubirali su od svih takse za pokrst i potom žene i djecu pustili kućama, a sve muškarce otpremili u Glinu i zatvorili u pravoslavnu crkvu. Preko noći izvršen je pokolj svih do posljednjeg..." Činjenica jest da je veći broj Srba iz okolice Vrginmosta stradao u tom pokolju, ali nisu do kraja rasvijetljene činjenice o broju ubijenih, na koji su način i na kojem mjestu spomenuti Srbi ubijeni. Na području općine Barilović u okolici Duge Rese od 926 pravoslavnih svega je njih dvoje prekršteno na rimokatoličku vjeroispovijest, a 14 "najavilo prijelaz". ${ }^{47} \mathrm{U}$ gradu Karlovcu između 12. rujna i 7. listopada 1941. izdane su 54 potvrde o čestitosti lokalnim Srbima, što bi značilo da su u mjesec dana svega 54 osobe tražile mogućnost za prekrštavanje na rimokatoličku vjeroispovijest. ${ }^{48}$ Mnogo je "plodnije" bilo u selima između Karlovca i Vrginmosta. Ondje je čitavo naselje Popović Brdo početkom siječnja 1942. prekršteno. ${ }^{49}$ Tek u svibnju 1942. nakon sukoba na Petrovoj gori, 38 obitelji iz sela Cerovac Tušilovićki, udaljenog od Karlovca tek nekoliko kilometara, prekršteno je na rimokatoličku vjeroispovijest, ${ }^{50}$ a $\mathrm{u}$ istom je mjesecu učinio isto i jedan dio pravoslavnih iz Brezove Glave i Tušilovića. ${ }^{51} \mathrm{U}$ lipnju su na rimokatoličku vjeroispovijest prekršteni mještani Ivanković Sela, Bukovice, Klipinog Brda, Mandić Sela, Kartalija, Udbinje i Manjerović Sela u kotaru Vojnić. Prekrštavanje je bilo skupno, a mještani su samo formalno prekršteni na rimokatoličku vjeroispovijest, budući da su se bojali odmazde ustaša nakon uništavanja partizana na Petrovoj gori. ${ }^{52}$ Opis samog prekrštavanja dao je župan Velike župe Pokuplje Viktor Gutić. Zbog sličnosti sa drugim masovnim javnim prekrštavanjima ovdje donosimo dijelove izvještaja: "Na dne 14. lipnja 1942. prije podne proveden je kod rimokatoličke crkve u Vukmaniću skupni prielaz žitelja grčkoistočnjaka na rimokatoličku vjeru, kojom je zgodom prešlo oko 4.000 vjernika sela Udbinje, Mandić Sela, Klipinog Brda, Ivanković Sela i Bukovice općine Vukmanić, Tušilovića i Brezove Glave općine Tušilović i Kartalija Sela općine Vojnić. (...) Mjesto Vukmanić bilo je iskićeno hrvatskim zastavama. U blizini crkve bio je podignut slavoluk, pred kojim je do $300 \mathrm{~m}$ s obje strane ceste bio postavljen špalir mladeži u slikovitoj narodnoj nošnji. Potom je govor održao načelnik

46 Arhiv Republike Slovenije, Urad za podržavljeno lastino NDH u Zagrebu, kutija 9, $17732 / 41$.

47 HDA, Državno ravnateljstvo za ponovu, vjerski odsjek, kutija 584, 343/1941.

48 HDA, MPB NDH, kutija 14, 4479-B-1941.

49 Nova Hrvatska, br. 11, 13. siječnja 1942.

50 HDA, MPB NDH, kutija 44, 5887-B-1942.

51 HDA, MPB NDH, kutija 44, 6061-B-1942.

52 HDA, MPB NDH, kutija 45, 6495-B-1942. 
općine Vukmanić koji je pozdravio župana i rekao sljedeće: 'Vaš dolazak, koji danas činite u ovom kraju i po ovome poslu od velike je važnosti i značenja za ovaj narod i ovaj kraj u ovome času, kada isti kao prielaznici sa grčko istočne vjere na rimokatoličku vrše skupni prielaz i to na svečani način, koji to čine, kako sam se osvedočio sa naročitom voljom i veseljem. (...) Današnji naši svečari - prielaznici - izrazili su također svoju želju, da se stope zajedno sa ostalom braćom Hrvatima, katolicima i vjerski i nacionalno i politički tako, da smo jedan narod, jedna vjera, jedna država i dao Bog, da se njihove želje na zadovoljstvo sviju nas potpuno ostvare.' Potom je Đuro Vukelić iz Donje Trebinje u ime prijelaznika održao govor u kojem je među ostalim rekao: 'Gospodine veliki župane, mi prielaznici sa pravoslavne na rimokatoličku vjeru učinili smo ovaj prielaz bez ikakvog pritiska ili nagovora težeći za tim, da se hrvatski narod stopi vjerski, nacionalno, politički i gospodarski, jer dok toga nema, nema podpunoga napredka..." U sličnom je stilu govor održao i Viktor Gutić, a potom je župnik iz Skakavca održao misu. ${ }^{53}$

Da bi sačuvali svoje živote, pravoslavni Srbi željeli su prekrštavanje i na baptističku vjeroispovijest. Međutim, Kotarska oblast u Ogulinu, kojoj su lokalni Srbi slali svoje molbe, nije pozitivno rješavala te molbe ne želeći da Srbi budu prekršteni na baptizam, već na rimokatoličku vjeroispovijest. Baptista je bilo najviše na području sela Trojvrh, Kunić, Janjagora i Begovac, odnosno na širem području Plaškog. Velika župa Modruš u Ogulinu smatrala je da Srbi na taj način žele izigrati državu i "dalje ostati prikriveni Srbi", ${ }^{54}$ pa je tražila da se ponište "svi vjerozakonski prijelazi s grčkoistočne na baptističku vjeroispovijest koji su učinjeni prije 10. travnja 1941", a kojih je prema evidenciji bilo $68 . .^{55}$ Podatak da je svega 38 osoba prekršteno na rimokatoličku vjeroispovijest na području kotara Ogulin do sredine studenog 1941. ukazuje na malobrojnost i nezainteresiranost pravoslavnih Srba za prekrštavanje. ${ }^{56}$ Ponešto drugačija situacija bila je na području općine Vrbovsko, gdje je u to vrijeme bio 171 pravoslavni. Ondje je prekršten na rimokatoličku vjeroispovijest 31 pravoslavac, a najavilo je prekrštavanje njih 107. ${ }^{57} \mathrm{Na}$ području Hrvatskih (nekadašnjih Srpskih) Moravica na rimokatoličku vjeroispovijest od ukupno 3.363 Srba prekršteno je 24, a najavilo prekrštavanje 379. ${ }^{58}$ Evidentno je da su pravoslavni u sredinama u kojima ih je bilo manje bili brže prekrštavani.

53 HDA, MPB NDH, kutija 46, 7018-B-1942.

54 HDA, MPB NDH, kutija 5, 454-B-1941.

55 HDA, MPB NDH, kutija 10, 2646-B-1941.

56 HDA, Državno ravnateljstvo za ponovu, vjerski odsjek, kutija 584, 217/1941.

57 HDA, Državno ravnateljstvo za ponovu, vjerski odsjek, kutija 584, 586/1941.

58 HDA, Državno ravnateljstvo za ponovu, vjerski odsjek, kutija 584, 611/1941. 
Banija (Petrinja, Sisak, Hrvatska Kostajnica, Dvor, Glina)

Kao i na Kordunu, Srbi s Banije bili su od samog početka uspostave NDH izloženi masovnim likvidacijama i najrazličitijim vrstama torture. U zonama Banije gdje je nasilja bilo manje vidljivo je da su pojedina sela gotovo u potpunosti prekrštavana na rimokatoličku vjeroispovijest. S petrinjskog područja krajem lipnja 1941. godine svi pravoslavni svećenici su prebjegli ili su bili prisilno iseljeni u Srbiju. Petrinjski paroh Galogaža prekršten je na grkokatoličku vjeroispovijest, a pravoslavni žitelji petrinjskog kraja nisu vodili svoju djecu na krštenja, dok su pokope obavljali bez svećenika i nisu ih uvodili u matice. Iz tih podataka je vidljivo kakvo je rasulo zavladalo u nekim bitnim trenucima ljudskog života nedostatkom crkvenih osoba na područjima odakle su prisilno iseljeni ili su pobjegli. ${ }^{59}$ Pojedina su sela tražila masovno, skupno prekrštavanje na rimokatoličku vjeroispovijest. Takav je slučaj bio sa selom Glinska Poljana između Gline i Petrinje. Ondje su pravoslavni seljaci 14. kolovoza 1941. tražili prekrštavanje na rimokatoličku vjeroispovijest za čitavo selo. ${ }^{60}$ Sličnu takvu dozvolu dobili su i pravoslavni stanovnici sela Mala Vranovina između Gline i Vrginmosta početkom rujna 1941. ${ }^{61}$ Masovno prekrštavanje tražili su i stanovnici Petkovca pokraj Petrinje 31. listopada 1941, njih 43, 159 stanovnika Moštanice, 63 stanovnika sela Stražbenica, 91 stanovnik Bijelnika, 118 stanovnika sela Blinja, od čega su brojni bili nepismeni. Svima je prekrštavanje odobreno 19. studenog 1941. godine. ${ }^{62}$ Stanovnici općine Blinja pisali su i pismo poglavniku u kojem ističu kako su "svi odlučili prihvatititi rimokatoličku vjeru koju smo i dosele poštivali...", a pozvali su se i na stanovništvo sela Letovanci koji su mogli potvrditi "da smo bili čestita vladanja prema braći Hrvatima". Na kraju molbe netko je iz ministarstva napisao crvenom olovkom "Pustiti ih na miru!"63 Slične skupne molbe predali su i stanovnici sela u okolici Sunje. Ondje su prekrštavanja najavljena za selo Novoselci, gdje je molbe podnijelo 12 obitelji, ${ }^{64}$ Donji Hrastovac, gdje su molbe podnijele 143 obitelji, ${ }^{65}$ sela Pobrđani gdje je molbe podnijelo 47 obitelji, 66 sela Čapljani, gdje je molbe podnijelo 35 obitelji67 i sela Staze gdje su molbe podnijele tri obitelji. ${ }^{68}$ Sve su molbe također podnijete u listopadu 1941. Skupne su molbe podnijela i sela Crkveni Bok sa 173 obitelji, Strmen sa 135 obitelji i Ivanjski Bok sa

59 HDA, MPB NDH, kutija 5, 558-B-1941. Galogaža je 1941. stradao.

60 HDA, MPB NDH, kutija 5, 727-B-1941.

61 HDA, MPB NDH, kutija 9, 2597-B-1941.

62 HDA, Državno ravnateljstvo za ponovu, vjerski odsjek, kutija 584, 81/1941.

63 HDA, MPB NDH, kutija 33, 3123-B-1942.

64 HDA, Državno ravnateljstvo za ponovu, vjerski odsjek, kutija 584, 91/1941.

65 HDA, Državno ravnateljstvo za ponovu, vjerski odsjek, kutija 584, 92/1941.

66 HDA, Državno ravnateljstvo za ponovu, vjerski odsjek, kutija 584, 94/1941.

67 HDA, Državno ravnateljstvo za ponovu, vjerski odsjek, kutija 584, 95/1941.

68 HDA, Državno ravnateljstvo za ponovu, vjerski odsjek, kutija 584, 93/1941. 
68 obitelji. ${ }^{69} \mathrm{U}$ ova sela dolazili su rimokatolički svećenici koji su uvjeravali lokalno stanovništvo da su njihovi djedovi bili Hrvati i da se oni sada trebaju vratiti vjeri djedova, prema iskazu Mile Požara iz Crkvenog Boka. ${ }^{70}$ Svi stanovnici Crkvenog Boka potpisali su izjavu kojom se obavezuju da će predati pravoslavnu crkvu novom rimokatoličkom župniku i da će mu podignuti novi župni stan. ${ }^{71}$ Usprkos tome što je u uputi Vjerskog odjela Državnog ravnateljstva za ponovu stajalo da sve "prijelaznike" treba "najustaškije zaštititi" sudbina stanovnika Crkvenog Boka, Strmena i Ivanjskog Boka bila je tragična budući da su spomenuti odvedeni u logor Jasenovac u listopadu 1942. Stanovništvo se vratilo svojim kućama nakon intervencije $s$ više strana. ${ }^{72}$ Molbe su predane i na području Četvrtkovca, Sunje, Radonja Luke i drugih sela u okolici Sunje gdje su 664 pravoslavna od njih 1.539 zatražili prekrštavanje do 28. listopada 1941, a svega in je 10 već bilo "prešlo na rimokatoličku vjeroispovijest". ${ }^{73}$ Stanovnici sela Drljače, Petrinjci i Greda, njih 95 s članovima obitelji, zatražili su prekrštavanje 5. prosinca $1941 .{ }^{74}$ O prekrštavanju sela Drljače izvijestio je dnevnik Hrvatski narod od 13. prosinca 1941. Svečanu misu služio je dekan Josip Orlić "koji u svom misionarskom radu među ovim narodom ima mnogo uspjeha". Župnik je održao i "divnu propovijed", a uz Te Deum pjevala se i ustaška i državna himna. ${ }^{75}$ Na području općine Gradusa u sunjskom kraju svi pravoslavni svećenici su izbjegli ili bili prisilno iseljeni, pa je općinsko poglavarstvo u Gradusi tražilo da se postavi matičar za parohije Brđani Vukoševački, Veliku Gradusu, Staro Selo i Svinicu. ${ }^{76}$ Vidljivo je da je za "prijelaznike" u sunjskom kraju organizirana bila i poduka u rimokatoličkom vjeronauku, i to za sela Bestrma, Staro Selo, Blinjski Kut, Kinjačka, Brđani, Vukoševac, Blinja i Velika i Mala Gradusa. Poduke su vrlo vjerojatno primala i druga sela, ali o tome u arhivskoj građi nisu nađeni podaci. Poduke u vjeronauku trajale su po dva tjedna (ili nešto više) a poduzete su u listopadu, studenom i prosincu 1941. godine. Poduku o "prijelazu s pravoslavne na rimokatoličku vjeroispovijest" na tome području provodili su kapucini iz Varaždina. ${ }^{77}$ Skupno su prekršteni i stanovnici sela Bestrma, Kinjačka, Klobučak i Blinjski Kut između Siska i Sunje, zatim žitelji Svinice kod Majura ${ }^{78}$ i stanovnici sela Mali Gradac pokraj

69 HDA, Državno ravnateljstvo za ponovu, vjerski odsjek, kutija 584, 96/1941.

70 V. Đ. Đurić, Prekrštavanje Srba u Nezavisnoj Državi Hrvatskoj, Prilozi za istoriju genocida, Beograd, 1991, str. 186.

71 HDA, MPB NDH, kutija 23, 7011-B-1941.

72 F. Škiljan, "Akcija Crkveni Bok", Radovi Zavoda za povijest Filozofskog fakulteta u Zagrebu, vol. 37 (2005), str. 325-342.

73 HDA, Državno ravnateljstvo za ponovu, vjerski odsjek, kutija 584, 332/1941.

74 HDA, Državno ravnateljstvo za ponovu, vjerski odsjek, kutija 584, 543/1941.

75 Hrvatski narod, 13. prosinca 1941.

76 HDA, MPB NDH, kutija 5, 455-B-1941.

77 HDA, MPB NDH, kutija 29, 1441-B-1942.

78 HDA, Državno ravnateljstvo za ponovu, Srpski odsjek, kutija 486, 16553/41. 
Gline. ${ }^{79}$ Masovna prekrštavanja su uslijedila na području općine Mečenčani, gdje je od ukupno 5.259 pravoslavnih njih 1.380 prekršteno na rimokatoličku vjeroispovijest, a 2.360 najavilo prekrštavanje do kraja studenog 1941.80 Na području Hrvatske Dubice bilo je krajem siječnja 1942. čak 797 obitelji koje su se željele prekrstiti na rimokatoličku vjeroispovijest. ${ }^{81}$ I na dvorskom području podnijete su molbe za prekrštavanja. Na sisačkom području u općini Topolovac živjela su 72 stanovnika pravoslavne vjeroispovijesti. Od 10. travnja 1941. do kraja studenog prekrštena su na rimokatoličku vjerosipovijest 52 pravoslavna, a devet je osoba najavilo prekrštavanje. ${ }^{82}$ Jedan dio stanovnika petrinjskog i glinskog kraja (ali i ostatka Banije) prekršten je na rimokatoličku vjeroispovijest u strahu da im se ne dogodi isto što i njihovim susjedima u Banskom Grabovcu. O tome svjedoče iskazi pojedinaca iz Komesarijata za izbeglice i preseljenike koji su prebjegli u Srbiju 1941. i kasnije. "Posle pokolja u Banskom Grabovcu išli su ustaše po našim selima i pozivali narod da pređe na rimokatoličku veru, obećavajući da nas posle toga neće niko progoniti", kako kazuje Sofija Marković iz Vlahovića. Nakon toga su stanovnici sela u okolici Banskog Grabovca, koje se uglavnom sastojalo od žena i djece budući da su muškarci pobjegli pred ustaškim terorom u šumu, prekršteni na rimokatoličku vjeroispovijest. U okolici Jabukovca nedaleko Petrinje postojao je veliki franjevački samostan u Hrvatskom Čuntiću. Franjevci su predlagali da između četiri i pet tisuća pravoslavaca koji su preživjeli mjere čišćenja i prisilnog iseljavanja, budu prekršteni na rimokatoličku vjeroispovijest i da se u tu svrhu sagradi što je moguće prije rimokatolička crkva na području Jabukovca i okolice. ${ }^{83}$ Vidljivo je da su se franjevci iz Čuntića trudili da pridobiju pravoslavne Srbe iz Jabukovca i okolice da pristanu na prekrštavanje. Bili su svjesni činjenice da je ključna osoba za pridobijanje pastve upravo lokalni pravoslavni svećenik. Branko Jakšić, pravoslavni svećenik iz Jabukovca, iznio je u Komesarijatu za izbeglice i iseljenike na koji su ga način franjevci iz Čuntića nagovarali na prekrštavanje na koje on nije pristao. Gvardijan samostana u Čuntiću došao je Jakšiću već početkom svibnja 1941. i nagovarao ga da zbog svoje sigurnosti "prijeđe na rimokatoličku vjeroispovijest" znajući da bi na taj način pridobio i veći dio njegove pastve. Međutim, Jakšić nije na to pristao. ${ }^{84}$

Posebnu pozornost zaslužuje župnik Franjo Žužek iz Gline. On je izdavao brojne potvrde o prekrštavanju pravoslavnom stanovništvu u okolici Gline i u Glini zato da bi ih spasio od ustaških progo-

79 HDA, MPB NDH, kutija 8, 1626-B-1941 i HDA, Državno ravnateljstvo za ponovu, Srpski odsjek, kutija 485, 16048/41.

80 HDA, Državno ravnateljstvo za ponovu, vjerski odsjek, kutija 584, 443/1941.

81 HDA, MPB NDH, kutija 29, 1475-B-1942.

82 HDA, Državno ravnateljstvo za ponovu, vjerski odsjek, kutija 584, 566/1941.

83 HDA, MPB NDH, kutija 21, bb/1941.

84 V. Đ Đurić, Prekrštavanje Srba u Nezavisnoj Državi Hrvatskoj, Prilozi za istoriju genocida, Beograd, 1991, str. 191-193. 
na. Milan Despot pišući o Glini 1941. spominje i Žužeka. "Počeo je (Franjo Žužek - op. a.) na veliko izdavati potvrde o prekrstu i slati ih u sela. Sve žene i djeca poubijanih Glinjana prekrštene su." ${ }^{\prime 85}$ Slično piše i Janko Mikšić: "Prekrštavanje Srba Franc Žužek provodio je specifično humano i formalno pa je to predstavljavalo samo dobijanje dokumenata o primitku u krilo svete rimokatoličke crkve... Da umiri stanovnike Majskih Poljana koji su zahtijevali da se pokrste, Žužek im je izdavao uvjerenja da su primljeni u rimokatoličku crkvu, a da vlastima dade na znanje da uživa autoritet među Srbima i da in tretira i zalaže se za njih kao ravnopravne građane, Žužek im je na raskršću u Majskim Poljanama dao sagraditi kapelicu kao u selima s rimokatoličkim vjernicima. Međutim, umjesto rimokatoličkog raspela... u kapelu je stavio ikonu Bogorodice...." 86 Tako je Žužek spasio više stotina Srba od progona, što je vidljivo i iz Urudžebnog zapisnika Nadbiskupskog duhovnog stola iz 1941. godine, gdje je jedan veliki broj odluka o prekrštavanjima upravo iz Gline. ${ }^{87}$

Iz navedenih primjera je vrlo jasno vidljivo da su pravoslavni Srbi na području Banije u pojedinim naseljima masovno "prelazili" na rimokatoličku vjeroispovijest. Najmasovnija prekrštavanja bila su na kostajničkom i petrinjskom području, u selima gdje 1941. i 1942. nije bilo zločina. U krajevima oko Banskog Grabovca i Gline, gdje su Srbi shvatili kakvi su krajnji ciljevi ustaških vlasti, najveći dio Srba nije "prelazio" na rimokatoličku vjeroispovijest, iako je i ondje bilo masovnih prekrštavanja u pojedinim selima. Muškarci su odavde odlazili u šumu i vodili gerilski rat protiv ustaških i njemačkih postrojbi, dok su žene, starci i djeca "prelazili" na rimokatoličku vjeroispovijest, ali usprkos tome vrlo često nedužni stradavali u ustaškim odmazdama.

85 Milan Despot, "Glina 1941", Prva godina narodnooslobodilačkog rata na području Karlovca, Korduna, Gline, Like, Gorskog kotara, Pokuplja i Žumberka, Karlovac, 1971 , str. 614.

86 Janko Mikšić, "Pod vodstvom KPH Hrvati i Srbi glinskog područja počinju 1941. godine zajedničku borbu za slobodu", Prva godina narodnooslobodilačkog rata na području Karlovca, Korduna, Gline, Like, Gorskog kotara, Pokuplja i Žumberka, Karlovac, 1971, str. 612-625, 637, 644.

87 Nadbiskupski arhiv Zagreb, Urudžbeni zapisnik Nadbiskupskog duhovnog stola za 1941. godinu, župa Glina moli prekrštavanje za 87 pravoslavaca 9. lipnja 1941. 6376/41; masovno prekrštavanje na području župe Glina (druga polovica lipnja 1941) 7348/41-7372/41; župni ured Glina traži prekrštavanje za 108 osoba 26. lipnja 1941. 7473/41; Glina traži masovna prekrštavanja (druga polovica lipnja) 7645/41-7649/41; masovna prekrštavanja na području Gline u srpnju 1941. (13157-13250/41); Glina prekrštavanja - prva polovica kolovoza (14194-14228, 14260-14312, 14322-14332, 14334-14343, 14354$14398,14400-14410$ i od 14412-14455, 14457-14490, 14527-14570, 1457614686/41; Maja - prekrštavanja 14491-14501/41, 14503-14505/41; Viduševac - masovno prekrštavanje 12 obitelji (16108/41); 16193/41 - Glina - masovno prekrštavanje 525 osoba; 16208/41 - Bučica - prekrštavanje 27osoba; 16613 Bučica prekrštavanje - 13 osoba, 16616/41 - Bučica prekrštavanje 11 osoba; 18111-18115/41 Bučica masovno prekrštavanje. 


\section{Bjelovarski kraj}

Na području Bjelovara prekrštavanja su bila masovnog karaktera. Do sredine studenog 1941. na području kotara Bjelovar prekršteno je čak 2.330 osoba s pravoslavne na rimokatoličku vjeroispovijest. Najveći broj prekrštavanja zabilježen je na području općine Farkaševac (1.050), Ivanska (460), Velika Pisanica (183), Veliko Trojstvo (142), Predavac (220) i Nova Rača (117). ${ }^{88}$ Od sredine studenog do siječnja 1942. na istom je području prekršteno još 887 osoba na rimokatoličku vjeroispovijest. ${ }^{89}$ Tada in je najviše prekršteno na području Gudovca (754). O tome kakav je bio karakter prekrštavanja na tome području govori pismo rimokatoličkog župnika iz Velike Pisanice. On se u listopadu 1941. godine žali kako se do tada "za prijelaz prijavilo svega 90 osoba" na području općine Velika Pisanica. Međutim, ističe kako još ima 1.300 osoba koje su "grčkoistočne vjeroispovijesti". Na području župe Velika Pisanica je krajem listopada 1941. objavljena naredba državne vlasti da svi "grčkoistočnjaci u najkraće vrijeme podnesu molbe ili će u protivnom slučaju biti svi otjerani u logore". Ova prijeteća naredba bila je proglašena u svim selima ove župe. Nakon toga bio je rezultat taj da su jednostavno izjavili: "Radije u logore i samu smrt, nego prijeći u Katoličku crkvu". S druge strane, partizani su im iz šume pretili da će im popaliti kuće ukoliko se prekrste na rimokatoličku vjeroispovijest. Župnik očajno zaključuje da "iskrenog prijelaza na rimokatoličku vjeroispovijest poslije ovakvog nastupa državnih vlasti ne može biti". "Sto više, otvoreno i javno se rugaju Crkvi i rkt. vjeri, govoreći: ako ćemo i učiniti tobože prijelaz, ali znajte da će nas šokački pop prvi i zadnji puta vidjeti u crkvi kod prijelaza i nikad više". Rimokatolički župnik je smatrao da pravoslavni vjernici Velike Pisanice i okolice "nisu vrijedni ni dostojni primiti ime rimokatolika". ${ }^{90}$ Jedan dio Srba prekršten je i na grkokatoličku vjeroispovijest. Evidentno je da se pri prekrštavanju na grkokatoličku vjeroispovijest nije diralo niti u stari obred, niti u crkveni jezik, niti u crkveni kalendar. Prema tome, osnovna razlika između grkokatolika i pravoslavnih bila je u tome što su grkokatolici prihvatili uniju, odnosno priznavali su papu za poglavara Crkve. Takvih je prekrštavanja bilo posebno mnogo na području Križevačke biskupije. Duhovni stol Križevačke biskupije tražio je stoga da se grkokatolicima vrati gradilište samostana Marče, manastir Lepavina i manastir Gomirje. Za Lepavinu su smatrali da je nekada pripadao sjedinjenoj marčanskoj biskupiji, ali su ga oteli doseljeni pravoslavci krajem sedamnaestog stoljeća, dok su za Gomirje isticali da je monah ondje bio jedan od marčanskih biskupa, Bazilije Predović, pa da je manastir stoga imao veliku ulogu u sjedinjenju 1611. godine. ${ }^{91} \mathrm{Uz}$ ove manastire biskup križevački Janko Šimrak zatražio je od Ministarstva pravosuđa i

88 HDA, Državno ravnateljstvo za ponovu, vjerski odsjek, kutija 584, 415/1941.

89 HDA, Državno ravnateljstvo za ponovu, vjerski odsjek, kutija 584, 768/1941.

90 HDA, MPB NDH, kutija 32, 2636-B-1942.

91 HDA, MPB NDH, kutija 11, 3128-B-1941. 
bogoštovlja i crkve u Velikoj Pisanici, Hrvatskoj Kapeli, Plavšincu, Velikim Bastajima, Velikom Vukovju, Salniku, Narti i Bjelovaru. ${ }^{92}$ Manastir Lepavina je početkom 1942. godine dodijeljen Križevačkoj biskupiji. ${ }^{93}$ Iz dopisa Janka Šimraka Ministarstvu pravosuđa i bogoštovlja vidljivo je da su 1942. grkokatoličkima postale nekadašnje pravoslavne parohije u Bolfanu, Velikoj Mučnoj, Velikom Pogancu, Koprivnici, Narti, Hrvatskoj Kapeli, Lipovčanima (?), Salniku i Križevcima. ${ }^{94}$ Tom popisu dodane su u svibnju 1942. i crkve u Plavšincu, Bjelovaru i Vojakovcu, ${ }^{95}$ a u lipnju u Velikim Bastajima, Marči i Bolču. ${ }^{96}$ Šimrak je tražio da se grkokatolicima dodijele i crkve u Bedeniku, Novoseljanima, Novim Pavljanima, Severinu, Gornjim Sredicama, Velikoj Barni, Velikom Grđevcu, Grubišnom Polju, Velikoj Peratovici, Velikoj Pisanici, Turčević Polju, Pašijanu i Bršljanici. ${ }^{97} \mathrm{U}$ bjelovarskom kotaru uspostavljena je grkokatolička župa u Bjelovaru sa selima Narta, Sredice, Gudovac, Prgomelje, Klokočevac i Stari i Novi Pavljani sa oko 2.000 vjernika. Njome je upravljao Janko Heraković. ${ }^{98}$ Janko Šimrak je tražio osnivanje i zasebne župe u Narti, za koju je tvrdio da broji oko 1.500 grkokatolika. Šimrak je tražio i crkvu u Srijedskoj, međutim, budući da ondje nitko nije prekršten na grkokatoličku vjeroispovijest, ta njegova molba je ostala bez svrhe. ${ }^{99}$

$\mathrm{Na}$ grubišnopoljskom području odaziv za prekrštavanje na rimokatoličku ili grkokatoličku vjeroispovijest nije bio osobit. Tako je na području općine Grubišno Polje od 3.321 pravoslavnih "najavilo prijelaz" na rimokatoličku vjeroispovijest svega njih 67, na području Ivanovog Sela od 1.844 pravoslavnih, svega njih 68, a na području Velikog Grđevca od 3.040 svega njih 68 do sredine studenog 1941. godine. ${ }^{100}$ Bez obzira na tako malu popularnost prekrštavanja na području Grubišnog Polja, Rimokatolička crkva imala je plan formirati nove rimokatoličke župe u Velikoj Barni s filijalama u Velikoj Jasenovači, Maloj Barni, Maloj Jasenovači, Malom Grđevcu i Grbavcu, te župu u Velikoj Peratovici s filijalama u Maloj Peratovici, Maloj Dapčevici, Velikoj Dapčevici, Lončarici, Topolovici i Gakovu. ${ }^{101}$

92 HDA, MPB NDH, kutija 29, 1580-B-1942.

93 HDA, MPB NDH, kutija 22, 1727-B-1942.

94 HDA, MPB NDH, kutija 40, 4972-B-1942.

95 HDA, MPB NDH, kutija 44, 5941-B-1942; 5973-B-1942. Lepavina je preuzeta službeno 17. ožujka 1942, Vojakovac, Velika Mučna i Veliki Poganac su preuzeti 24. svibnja 1942, Dišnik 25. svibnja 1942, Veliki Zdenci 26. svibnja 1942, Bjelovar i Plavšinci 31. svibnja 1942.

96 HDA, MPB NDH, kutija 46, 6961-B-1942.

97 HDA, MPB NDH, kutija 46, 6965-B-1942.

98 Stjepan Bunjevac, "Izvorni dokumenti OZNE o biskupu dr. Janku Šimraku i ,prekrštavanju' Srba u NDH", Glas koncila, 23 (1615), 5. lipnja 2005.

99 HDA, MPB NDH, kutija 61, 12468-B-1942.

100 HDA, Državno ravnateljstvo za ponovu, vjerski odsjek, kutija 584, 277/1941.

101 HDA, MPB NDH, kutija 11, 3075-B-1941. 
Dakle, u bjelovarskom kraju, gdje su prisilna iseljavanja u Srbiju, uz kotar Grubišno Polje, bila najmasovnija, bilo je mnogo prekrštavanja na rimokatoličku, ali i grkokatoličku vjeroispovijest. Broj grkokatolika, prema izvještajima Križevačke biskupije bio je vrlo velik, ali brojčani podaci nisu pouzdani. Cinjenica da je prema popisu stanovništva 1931. godine više od 20\% stanovništva kotara Bjelovar bilo pravoslavne vjeroispovijesti (bez grada Bjelovara, od 63.412 stanovnika bilo je 12.858 pravoslavne vjeroispovijesti), a da ih je do sredine 1942. prekršteno na rimokatoličku vjeroispovijest preko 3.000 govori o masovnosti prekrštavanja u okolici Bjelovara. U okolici Grubišnog Polja nije došlo do većih razmjera prekrštavanja s pravoslavne na grkokatoličku ili rimokatoličku vjeroispovijest zbog toga što je velik broj srpskih sela, kao i u općini Velika Pisanica, sabotirao prekrštavanje iz prkosa, ali i iz straha pred partizanskim akcijama.

\section{Moslavina (Garešnica, Čazma, Kutina)}

Veći broj Srba iz područja sjeverozapadne Hrvatske bio je prisilno iseljen u Srbiju preko iseljeničkih logora. Tako su Srbi iz Moslavine, iz sela oko Garešnice, u kolovozu 1941. odvedeni u logore u Bjelovar i Požegu odakle su trebali biti iseljeni u Srbiju. Pave Stanić, odvjetnik iz Kutine, podnio je molbu za osamdesetak obitelji iz toga kraja da ih državne vlasti vrate u njihove kuće pod uvjetom da spomenute obitelji "prijeđu na rimokatoličku vjeroispovijest". ${ }^{102}$ Vidljivo je iz dokumenata da su njihovi susjedi prekrštavani na rimokatoličku vjeroispovijest strahujući da bi im mogla biti oduzeta imovina, odnosno da će biti prisilno iseljeni sa svoje zemlje u Srbiju. Do 22. rujna 1941. na području kotara Garešnica izdano je 36 potvrda o čestitosti za pojedince i obitelji. Potvrde su izdane uglavnom ratarima i činovnicima, dok je 11 molbi odbijeno. Razlozi odbijanja molbi nisu navedeni, ali je vidljivo da su molbe, među ostalima, odbijene cestaru, lugaru, piljaru i Ciganinu. ${ }^{103}$ Dana 10. listopada odobren je "prijelaz na rimokatoličku vjeroispovijest" za trinaest obitelji iz Popovca, Prokopa i Dišnika nedaleko Garešnice. ${ }^{104}$ Takvih, pojedinačnih prekrštavanja bilo je mnogo te ih je i prema dokumentima u Hrvatskom državnom arhivu relativno teško pratiti.

U selu Dišnik pokraj Garešnice postojala je grkokatolička crkva od sredine 19. stoljeća, pa su stanovnici Dišnika, unatoč tome što su se državne vlasti protivile prekrštavanju pravoslavnih na grkokatoličku vjeroispovijest, tražili da im se dozvoli "slobodni povratak na vjeru naših pređa, a to u vjeru grkokatoličku, jer u našem selu već od 1842. postoji grkokatolička župa, pod koju spadaju naši djedovi,

102 HDA, MPB NDH, kutija 14, 4573-B-1941.

103 HDA, MPB NDH, kutija 14, 4377-B-1941.

104 HDA, MPB NDH, kutija 15, 4804-B-1941. 
a kako to svjedoče stare matične knjige ove župe". Dopis koji to traži potpisala su u listopadu 1941. 33 stanovnika sela Dišnik. ${ }^{105}$ Prema iskazu Janka Šimraka, administratora Križevačke biskupije, koji je dao pred organima OZN-e 1945. godine "svijet je bio zaplašen radi ubijanja, radi rušenja crkvi i radi prisilnoga prelaza na latinski obred, pa je tražio spas u Križevačkoj biskupiji, jer se u to vrijeme nije imao na koga drugoga obratiti". ${ }^{106}$ Istina je, također, kao što odgovara Janko Šimrak organima OZN-e da niti u jednom selu biskupija nije "dala inicijativu za prelaz, nego je tu incijativu dao sam narod". ${ }^{107}$ Međutim, Simrak je isto tako svjestan da prekrštavanja nisu bila iskrena, nego da su bila učinjena zbog spašavanja golog života i imovine. Iz dopisa Ordinarijata Križevačke biskupije u Križevcima vidljivo je koliku su vlast imali lokalni činovnici u pojedinim mjestima. Grkokatolički svećenik u selu Dišniku Aleksandar Vlasov pitao je tako 24. listopada 1941. lokalnog bilježnika Kunića u Garešnici zašto ne želi izdavati ljudima potvrde o "prijelazu na grkokatoličku vjeroispovijest", na što je on odgovorio da neće izdavati, a potom je počeo i vikati na Vlasova da je on bilježnik i da njemu nitko ništa ne može. Istog je dana saopćio Aleksandru Vlasovu, po nacionalnosti Ukrajincu, "da ne poduzima nikakvih koraka u vezi s prelazima, jer da će inače kao stranac biti lišen gostoprimstva Nezavisne Države Hrvatske..."108 Iz jednog ranijeg dopisa koji je uputio dekan i župnik iz Garešnice Mato Halauš u srpnju 1941. vidljivo je koliko se Rimokatolička crkva trudila da se pravoslavnim vjerniçima ne dozvoli da budu prekršteni na grkokatoličku vjeroispovijest. Župnik Halauš u svojem dopisu Ministarstvu pravosuđa i bogoštovlja piše kako se jedinstvo hrvatskog naroda kida dvojnim obredima, kako hrvatski narod nema povjerenja u grkokatolike, kako bi grkokatolički obred uvijek "opominjao nekadašnje pravoslavce da su oni nekada bili pravoslavni", kako grkokatolička crkva nije u stanju "ove pravoslavce niti vjerski niti nacionalno tako brzo i sigurno preparirati" i kako nije dobro da u selima zajedno žive grkokatolici i rimokatolici. ${ }^{109}$ Grkokatolike je Rimokatolička crkva pokušavala ocrniti kao unijate koji nisu Hrvati. ${ }^{110}$ Dakako, odnos rimokatolika prema grkokatolicima ovisio je ponajviše od župnika do župnika, ali prekrštavanja na grkokatoličku vjeroispovijest posebno su bila česta u krajevima sjeverozapadne Hrvatske (Podravina, Bjelovar, Moslavina), što je iritiralo lokalne rimokatoličke župnike koji su na taj način gubili pastvu. O pobuni protiv prekrštavanja pravoslavnih na grkokatoličku vjeroispovijest govori i činjenica da je nadstojnik vjerskog ureda Državnog ravnateljstva za ponovu Dionizije Juričev

105 HDA, MPB NDH, kutija 17, 5527-B-1941.

106 S. Bunjevac, ,Izvorni dokumenti OZNE o biskupu dr. Janku Šimraku i, prekrštavanju' Srba u NDH", Glas koncila, 18 (1610), 1. svibnja 2005.

107 Ibid.

108 HDA, MPB NDH, kutija 18, 5574-B-1941.

109 HDA, MPB NDH, kutija 3, 43807/41.

110 HDA, MPB NDH, kutija 18, 5590-B-1941. 
napisao oštar prosvjed poglavniku u vezi s prekrštavanjima na grkokatoličku vjeroispovijest. On je smatrao da iznad 2/3 grkokatolika u NDH nisu Hrvati već stranci, da su većina svećenika Grkokatoličke crkve stranci, da većina grkokatolika nije surađivala s Hrvatima za vrijeme bivših režima, da raštrkane pravoslavce koji su prekršteni na grkokatoličku vjeroispovijest Grkokatolička crkva neće moći pastorizirati te da će većina grkokatolika "prijeći" na pravoslavnu vjeroispovijest prvom prilikom. ${ }^{111}$ Zbog prisilnog iseljavanja pravoslavnih svećenika stanovnici pravoslavne vjeroispovijesti na području općine Vukovje nisu krstili svoju djecu. Tako kotarska oblast Garešnica zabranjuje "pokrštavanje djece grčkoistočnih roditelja po grkokatoličkom odnosno po grčkoistočnom svećeniku". ${ }^{112}$ Iz toga je dopisa jasno vidljivo da su lokalne vlasti smatrale da su pravoslavni i grkokatolici jednako nepoželjni.

Na garešničkom području pravoslavni koji su se prijavili za prekrštavanje na rimokatoličku vjeroispovijest na sve su moguće načine izbjegavali da dolaze u rimokatoličku crkvu. Naime, sela oko Kaniške Ive nisu imala rimokatoličke crkve osim one u Kaniškoj Ivi. Kako se ona nalazila od pojedinih sela i po nekoliko kilometara daleko, tražili su da župnik iz Kaniške Ive sam dolazi njima. ${ }^{113}$ Iz statističkih podataka o broju prekrštenih na garešničkom području vidljivo je da su od ukupno 6.136 pravoslavnih žitelja na području kotara Garešnica, njih 3.823 zatražili potvrdu o čestitosti "u svrhu prijelaza na rimokatoličku vjeroispovijest", dok ih 2.313 nije zatražilo "prijelaz". Pitanje je koliko je njih uistinu i prekršteno na rimokatoličku vjeroispovijest, budući da je jedan dio Srba iz kotara Garešnica, usprkos tome što su najavili "prijelaz na rimokatoličku vjeroispovijest", bio interniran u iseljeničke logore. ${ }^{114}$ Upravo zbog prisilnog iseljavanja Srba s područja kotara Garešnica vidljivo je iz brojnih dokumenata sačuvanih u Hrvatskom državnom arhivu da se većina onih koji su zatražili "potvrdu o čestitosti" nisu odlučili da "prijeđu" na rimokatoličku, odnosno grkokatoličku vjeroispovijest. Prema pisanju župnika Josipa Đurića u Kaniškoj Ivi, Srbi iz kotara Garešnica bili su toliko preplašeni prisilnim iseljavanjem njihovih susjeda da su u selima koja su iseljavana stanovnici širili lažne i neprovjerene informacije da će oni koji se prekrste biti iseljeni u Bosnu, a oni koji ne prekrste u Srbiju. Župnik Đurić piše da se stanovnici pravoslavnih sela koji su se prijavili "za prijelaz na rimokatoličku vjeroispovijest" nisu ni odazvali podučavanjima koja su bila obavezna za sve prekrštene. Đurić je smatrao da se pravoslavci ne odazivaju na podučavanja i "ne prelaze na rimokatoličku vjeroispovijest" zbog grkokatoličke propagande koju provodi župnik iz Dišnika Aleksandar

111 HDA, Državno ravnateljstvo za ponovu, vjerski odsjek, kutija 584, 282/1941.

112 HDA, Državno ravnateljstvo za ponovu, vjerski odsjek, kutija 584, 184/1941.

113 HDA, Državno ravnateljstvo za ponovu, vjerski odsjek, kutija 584, 232/1941.

114 HDA, MPB NDH, kutija 46, 7060-B-1942. 
Vlasov. ${ }^{115}$ Ministarstvo unutarnjih poslova smatralo je da Vlasova, u slučaju dalje propagande, treba ukloniti s mjesta grkokatoličkog župnika u Dišniku. ${ }^{116}$ U studenom 1941. župnik Đurić iz Kaniške Ive je predložio da se na područje pravoslavnih sela u okolici Garešnice pošalje šest misionara koji bi stanovali u nekadašnjim parohijskim stanovima i koji bi izvršili "brze prijelaze pravoslavnih vjernika na rimokatoličku vjeroispovijest". $117 \mathrm{U}$ travnju 1942. pravoslavne crkve u selima Stupovača i Veliko Vukovje ${ }^{118}$ predane su Rimokatoličkoj crkvi, odnosno postale su filijale župi u Kaniškoj Ivi. Do tada je na području ove dvije parohije 1.320 osoba prekršteno na rimokatoličku vjeroispovijest. ${ }^{119}$ Župa u Dišniku trebala je biti osnovana u lipnju 1942. budući da je brojila 3.250 osoba koje su sa pravoslavne prekrštene na grkokatoličku vjeroispovijest, prema iskazu križevačkog administratora Janka Šimraka. Teritorijalno, ova je župa obuhvaćala i sela nekadašnjih pravoslavnih parohija Pašijan, Bršljanica i Veliki Zdenci. ${ }^{120} \mathrm{U}$ selima Kutinica i Čaire ${ }^{121}$ stanovništvo je nakon interniranja Srba u iseljeničke logore u kolovozu 1941. odlučilo da se nikako neće prekrstiti pod izgovorom "da im je njihova vjera vjera njihovih otaca i jedina duševna hrana i da u toj svojoj grčkoistočnoj vjeri mogu biti vjerni podanici naše države". ${ }^{122}$ Slično je bilo i na području Rogože i Velike Bršljanice, ${ }^{123}$ gdje se pravoslavni također nisu htjeli prekrstiti

115 Vlasova su ubili partizani 26. srpnja 1942. O tome je iskaz dala njegova supruga predstavnicima Križevačke biskupije. (HDA, MPB NDH, kutija 49 a, 8489-B-1942)

116 HDA, MPB NDH, kutija 28, 1157-B-1942.

117 HDA, MPB NDH, kutija 32, 2658 - B - 1942.

118 Interesantan je dokument iz svibnja 1942. u kojem Janko Šimrak moli za dozvolu da blagoslovi bivše pravoslavne crkve u Dišniku, Velikom Vukovju i Velikim Zdencima. Nije posve jasno kako bi grkokatolički administrator Križevačke biskupije mogao blagosloviti crkvu koja je pripala rimokatoličkoj župi u Kaniškoj Ivi (HDA, MPB NDH, kutija 43, 5644-B-1942). Iz odluke Ministarstva pravosuđa i bogoštovlja od 7. rujna 1942. vidljivo je da prilikom osnutka grkokatoličke župe u Velikom Vukovju - Stupovači grkokatolicima nije predana crkva u Velikom Vukovju budući da je već prije predana rimokatolicima, a za crkvu u Stupovači napisano je da će biti izdan poseban nalog Kotarskoj oblasti u Garešnici. (HDA, MPB NDH, kutija 56, 10936-B-1942).

119 HDA, MPB NDH, kutija 39, 4717-B-1942.

120 HDA, MPB NDH, kutija 47, 7614-B-1942. Pitanje je koliko je točna brojka od 3.250 pravoslavnih koji su prekršteni na grkokatoličku vjeroispovijest. U popisu od 14. ožujka 1942. svega je trideset i jedna osoba s područja župe Dišnik regularno bila primljena u grkokatoličku vjeroispovijest, dok ostali prema državnim zakonima to nisu bili. O tome je pisao i sam župnik Aleksandar Vlasov. HDA, Sekretarijat državne sigurnosti republičkog sekretarijata unutarnjih poslova Socijalističke Republike Hrvatske (dalje SDS RSUP SRH), 013.0.64, kopija dokumenta MPB NDH, kutija 9765-B-1942)

121 U Čairama je bez obzira na tu činjenicu u veljači 1942. 17 pravoslavnih prekršteno na rimokatoličku vjeroispovijest. (HDA, MPB NDH, kutija 30, 1918-B-1942)

122 HDA, Državno ravnateljstvo za ponovu, vjerski odsjek, kutija 584, 521/1941.

123 Među pravoslavnima Velike Bršljanice propagandu za prekrštavanje na grkokatoličku vjeroispovijest vršio je nekadašnji pravoslavni svećenik Ivan Mračkovski, Ukrajinac, koji je vraćen iz logora u Capragu, odakle je trebao biti transportiran u 
ni na grkokatoličku ni na rimokatoličku vjeroispovijest. Na području općine Berek, koja je u to vrijeme pripadala kotaru Garešnica, krajem listopada 1941. prekršteno je 88 pravoslavnih vjernika iz Bereka, Ruškovca, Begovače, Oštrog Zida, Krivaje, Potoka i Podgarića na rimokatoličku vjeroispovijest. ${ }^{124}$ Do prosinca 1941. broj obitelji koje su najavile prekrštavanje na berečkom području, odnosno koje su već bile prekrštene, iznosio je $104 .{ }^{125}$ Poseban slučaj bio je na području garešničkog kotara u selu Veliki Zdenci, gdje je 57 obitelji zatražilo "prijelaz na grkokatoličku vjeroispovijest" koji im je odobren 24. srpnja $1941 .{ }^{126} \mathrm{U}$ dopisu koji je poslan svega dva dana nakon toga poglavniku NDH vidljivo je kako brojni stanovnici Velikih Zdenaca mole primanje u Rimokatoličku ili Grkokatoličku crkvu, odnosno Hrvatsku narodnu zajednicu te mole zaštitu. ${ }^{127}$ Međutim, nedugo potom odlaze tri izaslanika nekadašnjih pravoslavaca iz Velikih Zdenaca u Državno ravnateljstvo za ponovu i traže da se poništi prekrštavanje na grkokatoličku vjeroispovijest svih 57 obitelji, tj. da ih se primi u Rimokatoličku crkvu. Dana 29. rujna poništava se prekrštavanje nekadašnjih pravoslavaca na grkokatoličku vjeroispovijest i omogućava im se prekrštavanje na rimokatoličku vjeroispovijest. Kotarska oblast u Garešnici obavještava nekadašnje pravoslavce da njihovo prekrštavanje na grkokatoličku vjeroispovijest ionako nije bilo zakonski valjano, pa da oni zapravo nisu prekršteni na grkokatoličku vjeroispovijest, budući da u blizini, odnosno na njihovom teritoriju ne postoji grkokatolička

Srbiju. (HDA, MPB NDH, kutija 32, 2656-B-1942). Osnivanjem Hrvatske pravoslavne crkve Mračkovski je tražio da bude postavljen za paroha u Bršljanici, ali da opslužuje i parohije u Velikom Pašijanu, Stupovači, Mikleuški, Srijedskoj i Velikom Vukovju). (HDA, MPB NDH, kutija 43, 5786-B-1942).

124 HDA, MPB NDH, kutija 22, 5408-B-1941.

125 HDA, Državno ravnateljstvo za ponovu, vjerski odsjek, kutija 584, 599/1941.

1260 tome prekrštavanju na grkokatoličku vjeroispovijest iskaz je dala Bosiljka Kekuš, koja je nakon što je prebjegla u Srbiju ovako izjavila u Komesarijatu za izbeglice i preseljenike: "Prošle godine (1941. - op. a.) nakon proglašenja Nezavisne Države Hrvatske, vršio je ustaški poverenik za srez garešnički Račan Miško, zemljoradnik iz Velikih Zdenaca, pritisak na Srbe da pređu na grčko-katoličku veru, preteći im da će ih u protivnom slučaju sve oterati sa njihovih poseda i iseliti u Crnu Goru. Pri tom ih je opominjao rečima: ,Ako se kome šta desi, ne krivite mene.' Račan je svojim prijateljima u poverenju govorio da Srbe treba najpre prevesti na grčko-katoličku veru, a onda će ih posle biti lako prevesti u rimokatoličku. Narod se prepao, pa je pristao da pređe na rimokatoličku veru. Na pravoslavne Duhove prošle godine došao je iz Križevaca u Velike Zdence grčkokatolički biskup sa grčkokatoličkim sveštenikom iz sela Dišnik Vlasov Aleksandrom, te više drugih sveštenika i izvršio pokrštavanje Srba iz Velikih Zdenaca. Taj isti dan pretvorena je srpsko-pravoslavna crkva u Velikim Zdencima u grčkokatoličku i kao takova osvećena po grčkokatoličkom biskupu. Posle izvršenih prelaza na grčkokatoličku veru, bili su Srbi u onom kraju uglavnom mirni i niko ih nije dirao sve do najnovijeg vremena. Grčkokatolički svešetnik iz Dišnika navedeni Vlasov Aleksandar dolazio je često puta u Velike Zdence i služio grčkokatoličku službu. Narod je išao u crkvu jer je morao." (V. Đ. Đurić, Prekrštavanje Srba u Nezavisnoj Državi Hrvatskoj, Prilozi za istoriju genocida, Beograd, 1991, str. 165-166)

127 HDA, MPB NDH, kutija 42, 5285-B-1942. 
župa. Najbliža grkokatolička župa nalazila se u Dišniku, koji je od Velikih Zdenaca udaljen više desetaka kilometara. ${ }^{128}$ Janko Šimrak, apostolski administrator Križevačke biskupije, žalio se zbog poništavanja prekrštavanja grkokatolika iz Velikih Zdenaca budući da su "prijelaznici" već uneseni u matice prijelaznika, ispovijedani i pričešćeni, a radi se uostalom "o jednoj jedinoj katoličkoj crkvi" pa im se ne mogu izdavati ponovne odluke "o prijelazu u katoličku vjeroispovijest". ${ }^{129}$ Razlozi njihovu prekrštavanju na rimokatoličku vjeroispovijest leže u činjenici da je jedan dio "prijelaznika", bez obzira na činjenicu što su prekršteni na grkokatoličku vjeroispovijest, odveden u iseljenički logor u Bjelovar, a kasnije u Požegu, odakle su pušteni tek krajem listopada i početkom studenog 1941. Vrlo je vjerojatno ta činjenica ostale "prijelaznike" uvjerila da im se ne isplati prekrštavati na grkokatoličku vjeroispovijest. Nakon vraćanja interniranih Srba kućama, načelnik kotara Garešnica pitao je jednom prilikom jednog od njih da li "namjerava prijeći na rimokatoličku vjeroispovijest", na što mu je ovaj odgovorio da neće jer ne mora. Drugi su mu odgovorili da su se prilikom izlaska iz logora Požega obavezali da će "prijeći na rimokatoličku vjeroispovijest". ${ }^{130}$

Na području kotara Čazma do sredine prosinca 1941. za prekrštavanje se prijavilo 12 pravoslavnih dok ih je 43 već prekršteno na rimokatoličku vjeroispovijest, ${ }^{131}$ a tokom prosinca na rimokatoličku vjeroispovijest prekrštene su 22 osobe, zatražilo prekrštavanje 14 osoba, a za prekrštavanje se nisu najavile 392 osobe. ${ }^{132}$ Kao i u garešničkom kotaru, početkom kolovoza 1941. jedan veći broj Srba iz kotara Čazma odveden je u logor u Bjelovar, odakle su svi prisilno iseljeni u Srbiju. Prekrštavanja je bilo i na grkokatoličku i na rimokatoličku vjeroispovijest, iako se kotarska vlast u Čazmi svojski trudila da prekrštavanja s pravoslavne vjeroispovijesti budu jedino na rimokatoličku vjeroispovijest. Kotarski predstojnik u Čazmi požalio se tako Ministarstvu pravosuđa i bogoštovlja da je dr Bukatko iz Križevaca nagovarao stanovnike kotara Čazma da se prekrste na rimokatoličku vjeroispovijest, a kada se osnuje grkokatolička župa u Marči ili Lipovčanima da se prekrste na grkokatolicizam i da na taj način zavaraju vlasti. ${ }^{133}$ Bukatko je pisao jednom od budućih "prijelaznika" ovako: "Dakle, iz ovoga svega savjetuje Vam se da ako možete još malo sačekate dok se sve to rieši, pa čekajte, a ako su baš mjesne vlasti silom odlučile da Vas proti Vaše volje prevedu samo u rimoka-

128 Crkvu u Velikim Zdencima snašla je loša sudbina. Naime, krajem 1942. u već oštećenu crkvu naselila se vojska koja je crkvu do kraja devastirala. O tome je izvještaj dao Janko Šimrak Ministarstvu Hrvatskog domobranstva te je tražio da se iz crkve odstrane vojnici. (HDA, MPB NDH, kutija 64, 66-B-1943)

129 HDA, MPB NDH, kutija 18, 5592-B-1941; 5257-B-1941.

130 HDA, Državno ravnateljstvo za ponovu, vjerski odsjek, kutija 584, 521/1941.

131 HDA, Državno ravnateljstvo za ponovu, vjerski odsjek, kutija 584, 642/1941.

132 HDA, Državno ravnateljstvo za ponovu, vjerski odsjek, kutija 584, 773/1941.

133 HDA, MPB NDH, kutija 43, 5537-B-1942. 
tolički obred, to da ne dodjete u kakovu veću opasnost i da izbjegnete nepotrebna natezanja možete se prijaviti k njima, ali slobodno recite rimokatoličkom svećeniku da ste mu se prijavili samo zato jer vas općinske vlasti na to nagone, inače da želite biti pravi katolici samo u svom istočnom, grkokatoličkom obredu, i da Vam je rečeno da će se otvoriti grkokatoličke župe i u vašoj okolici, i kad se otvore, da će sam zagrebački nadbiskup odrediti, da Vi spadate u grkokatoličku parohiju, koja će biti najbliže Vama."134 U kotaru Čazma očito su kotarske vlasti bile vrlo neraspoložene prema prekrštavanjima na grkokatoličku vjeroispovijest. Selo Koritna, koje je prekršteno na grkokatoličku vjeroispovijest, dobilo je pismeni nalog od kotara Cazma preko općinskog poglavarstva u Dubravi da se u roku od tri dana moraju prekrstiti na rimokatoličku vjeroispovijest. Tome se suprotstavio Janko Šimrak, smatrajući da su tamošnja prekrštavanja obavljena bez ikakvih pogrešaka. ${ }^{135}$ Kotarski se načelnik ispravio u dopisu Ministarstvu pravosuđa i bogoštovlja prestiliziravši svoju naredbu tako da oni "pravoslavci koji su prešli na grkokatoličku vjeru ostanu nesmetano u toj vjeri". ${ }^{136}$ Ipak, evidentno je, kao što svjedoči i biskup Šimrak u svojem iskazu OZN-i, da su kotarske vlasti u Čazmi zauzele crkvu i parohijalni dom u Lipovčanima zato da on ne bi pripao Grkokatoličkoj crkvi. ${ }^{137} \mathrm{Na}$ području parohije Lipovčani od 621 vjernika pravoslavne vjeroispovijesti, do sredine 1942. je njih 334 prekršteno na rimokatoličku vjeroispovijest, 110 in je zatražilo prekrštavanje, a 177 ih uopće nije zatražilo prekrštavanje, pa su stanovnici sela Donji Lipovčani zahtijevali da se crkva preuredi u rimokatoličku. ${ }^{138}$ Šimrak je poslao grkokatoličkog svećenika u Lipovčane da održi službu za Božić 1942. godine, ali mu to nije bilo dozvoljeno. ${ }^{139}$ Parohiju u Marči preuzela je Križevačka biskupija 14. lipnja 1942. te su tražili da im se dodijeli i 35 rali zemlje oko nekadašnjeg manastira koja je pripadala prisilno iseljenom Srbinu Savi Vraneševiću, a na kojoj su bili naseljeni Slovenci. ${ }^{140}$ Križevačka biskupija također je predložila da se omanja pravoslavna kapelica na mjestu manastira u Marči poruši i da se tokom 1943. godine osigura milijun kuna da bi se podigao veliki samostan. ${ }^{141}$

Na kutinskom području selo Mikleuška je krajem rujna čitavo prekršteno na rimokatoličku vjeroispovijest. To su učinili isključivo zato da ih se prisilno ne iseli u Srbiju, pa i u dopisu stoji da kotarska oblast "ima odrediti da se ova lica ne smetaju osim ako se ogriješe o

134 HDA, MPB NDH, kutija 43, 5537-B-1942.

135 HDA, MPB NDH, kutija 43, 5644-B-1942.

136 HDA, MPB NDH, kutija 44, 6024-B-1942.

137 S. Bunjevac, ,Izvorni dokumenti OZNE o biskupu dr. Janku Šimraku i ,prekrštavanju' Srba u NDH", Glas koncila, 19 (1611), 8. svibnja 2005.

138 HDA, MPB NDH, kutija 48, 8215-B-1942.

139 HDA, MPB NDH, kutija 65, 352-B-1943.

140 HDA, MPB NDH, kutija 46, 6961-B-1942.

141 HDA, MPB NDH, kutija 56, 10602-B-1942. 
postojeće zakonske odredbe". ${ }^{142}$ Na području čitave kotarske oblasti Kutina do početka prosinca 1941. na rimokatoličku vjeroispovijest prekrštena su 1.073 pravoslavna, najavila su prekrštavanje 292, a nisu najavila prekrštavanje 222 pravoslavna. ${ }^{143}$ Čini se da je najveći broj onih koji su prekršteni na rimokatoličku vjeroispovijest bio upravo na području nekadašnje parohije u Mikleuškoj. Iz tog razloga trebalo je osnovati i novu župu u Mikleuškoj pod koju su, prema prijedlogu župnika iz Kutine, trebala pripadati sela Ciglenica, Mikleuška, Selište, Kutinica, Čaire, Kletište i Slatina. Župnik Želimir Liko je postavljen u prosincu 1941, a župa je u to vrijeme brojila oko 3.000 rimokatolika i 400 pravoslavnih, od kojih su mnogi "najavili svoj prijelaz" na rimokatoličku vjeroispovijest. ${ }^{144}$

Specifična situacija u Moslavini stvorena je bila prisilnim iseljavanjem srpskog pravoslavnog stanovništva iz kotara Garešnica i Cazma: specifična zato što je cjelokupno internirano stanovništvo kotara Garešnica vraćeno svojim kućama jer Nijemci u Srbiji više nisu željeli primati iseljenike. Evidentno je također da su pravoslavni iz kotara Garešnica nakon odvođenja u internaciju 531 osobe radi prisilnog iseIjavanja u Srbiju postali sumnjičavi i prema prekrštavanju, te im se ta opcija nije činila suviše sigurnom. Stoga su čekali dalji razvoj situacije. Sto se kotara Čazma tiče, ondje je Grkokatolička crkva, kao i na garešničkom području, pokušala privući vjernike nekadašnje Srpske pravoslavne crkve. Međutim, čini se da u tome nisu uspjeli budući da su se tome iznimno energično odupirale lokalne vlasti. U nekoliko navrata križevački je administrator zahtijevao povrat zemljišta na kojem je stajao manastir Marča. Međutim, usprkos tome što je manastirsko zemljište vraćeno, novi manastir, kako je predviđala Križevačka biskupija, nikad nije sagrađen. Na kutinskom području, gdje su Srbi bili smješteni u sjeveroistočnom dijelu kotara, gotovo je čitava pravoslavna populacija prekrštena na rimokatoličku vjeroispovijest.

\section{Kalnički kraj (Križevci, Novi Marof)}

Kao i u okolici Garešnice i Bjelovara, i u okolici Križevaca bilo je pokušaja prekrštavanja na grkokatoličku vjeroispovijest. Na križevačkom području postojala je župa u Prgomeljama i u Križevcima, gdje je ujedno bilo i sjedište Križevačke biskupije. Ondje su pravoslavni pokušavali "prijeći na grkokatoličku vjeroispovijest", ali im je rijetko kada to uspijevalo. Naime, rimokatoličke župe Rovišće, Kraljevac i Remetinec pobunile su se protiv toga da pravoslavni "prelaze na grkokatoličku vjeroispovijest" na temelju male grkokatoličke župe u Prgomeljama, odnosno grkokatoličke biskupije u Križevcima, mada u blizini postoje rimokatoličke župe. Pravoslavni su se mimo zakonske odredbe od 30. srpnja 1941. upisivali u grko-

142 HDA, MPB NDH, kutija 13, 3720-B-1941.

143 HDA, Državno ravnateljstvo za ponovu, vjerski odsjek, kutija 584, 551/1941.

144 HDA, MPB NDH, kutija 43, 5531-B-1942. 
katoličke matice Svete trojice u Križevcima, što je prema mišljenju lokalnih organa vlasti bilo protuzakonito. ${ }^{145}$ Grkokatolička župa u Prgomeljama tvrdila je da se teritorij, odnosno jurisdikcija te župe proteže na području tadašnjih kotareva Bjelovar, Đurđevac, Čazma i dio kotara Križevci, ${ }^{146}$ tako da je grkokatolički župnik iz Prgomelja imao pravo vršiti prekrštavanja na grkokatoličku vjeroispovijest na teritoriju tih kotara prema prvoj točci zakonske odredbe od 30. srpnja 1941. u kojoj stoji da grkoistočnjaci "ne prelaze na grkokatolički obred osim u onim grkokatoličkim župama koje su već osnovane i u njima ima grkoistočnjaka". ${ }^{147}$ Državno ravnateljstvo za ponovu je na temelju zakonske odredbe od 30. srpnja 1941. odlučilo da molbe za prekrštavanje pravoslavaca na grkokatoličku vjeroispovijest na području općine Sveti Ivan Žabno treba odbiti. ${ }^{148}$ Ipak, iz statističkih izvještaja koje su općine slale Državnom ravnateljstvu za ponovu vidljivo je da je od 689 pravoslavnih njih 18 "prešlo na rimokatoličku vjeroispovijest", 95 na grkokatoličku vjeroispovijest, 270 ih je najavilo "prijelaz", a 70 ih je "podnijelo molbe za prijelaz". ${ }^{149}$ Do sredine 1942. na području parohije Sveti Ivan Žabno prekršteno je 240 osoba na grkokatoličku vjeroispovijest prema izvještaju Križevačke biskupije, ${ }^{150}$ a svega 21 na rimokatoličku. ${ }^{151}$ Do tog vremena sveukupno su 383 osobe najavile prekrštavanje na rimokatoličku ili grkokatoličku vjeroispovijest. ${ }^{152}$ Prema jednom izvještaju iz 1942. godine čini se da je grkokatolički svećenik iz Prgomelja nagovarao pravoslavne da se prekrste na grkokatoličku vjeroispovijest, što je prema pisanju velikog župana Velike župe Bilogora stvaralo kod njih zabunu, pa oni više nisu znali na koju bi se vjeroispovijest prekrstili. Uz to, grkokatolički župnik u Prgomeljama bio je Rus, bivši pravoslavac, koji je zabranio rimokatoličkom življu iz Prgomelja da pjevaju rimokatoličke pjesme u grkokatoličkoj crkvi za Božić, pa su rimokatolici, koji su nekada odlazili u grkokatoličku crkvu u Prgomeljama, prestali odlaziti u crkvu. Veliki župan je zahtijevao da se ta agitacija prekine. ${ }^{153} \mathrm{U}$ samom gradu

145 HDA, Državno ravnateljstvo za ponovu, vjerski odsjek, kutija 584, 83/1941.

146 Grkokatolička župa u Prgomeljama obuhvaćala je u konačnici teritorij bivših parohija u Bolču, Rovišću, Gudovcu, Kablu i Klokočevcu. Prema izvještaju Janka Šimraka na grkokatoličku vjeroispovijest je na tome području od ukupno 4.200 pravoslavnih prešlo 3.000. (HDA, MPB NDH, kutija 47, 7615-B-1942)

147 HDA, MPB NDH, kutija 18, 5601-B-1941.

148 HDA, Državno ravnateljstvo za ponovu, vjerski odsjek, kutija 584, 82/41.

149 HDA, Državno ravnateljstvo za ponovu, vjerski odsjek, kutija 584, 252/1941.

150 HDA, MPB NDH, kutija 46, 7047-B-1942.

151 HDA, MPB NDH, kutija 47, 7384-B-1942.

152 HDA, SDS RSUP SRH, 013.0.64, kopija dokumenta MPB NDH, kutija 7384-B1942.

153 HDA, MPB NDH, kutija 29, 1866-B-1942. Pavao Šimljanski bio je ruski emigrant koji je prešao s pravoslavlja na grkokatoličku vjeroispovijest. Budući da nije bio posebno popularan u Prgomeljama, premješten je iz ovog naselja u Bolč, gdje je bilo oko 1.000 vjernika koji su prešli na grkokatoličku vjeroispovijest. (S. Bunjevac, "Izvorni dokumenti OZNE o biskupu dr. Janku Šimraku i, prekrštavanju' Srba u $\mathrm{NDH}^{\prime \prime}$, Glas koncila, 24 (1616), 12. lipnja 2005). Posebno je zanimljiva činjenica da je Mijo Jurić, vojnički dušobrižnik u Bjelovaru, javno napadao Janka Šimraka zbog toga što je postavio Pavla Šamiljskog za svećenika u Prgomeljama, a Šamiljski 
Križevci živjelo je relativno malo pravoslavnih žitelja. Od njih 37, 24 su već prekršteni na rimokatoličku vjeroispovijest, devet na grkokatoličku, a četiri su najavili prekrštavanje. ${ }^{154}$ Kasnije se broj prekrštavanja povećao, pa je do sredine 1942. 70 osoba iz Križevaca prekršteno na rimokatoličku vjeroispovijest i 17 na grkokatoličku vjeroispovijest. ${ }^{155}$ I selo Vojakovac prekršteno je na grkokatoličku vjeroispovijest. Ondje je za župnika postavljen Josip Melenjuk. Prema izvještaju općinskog poglavarstva, u Vojakovcu su do kraja svibnja 1942. od 266 pravoslavnih obitelji 23 prekrštene na rimokatoličku vjeroispovijest, a 200 obitelji na grkokatoličku vjeroispovijest. Općinsko poglavarstvo je u izvještaju Kotarskoj oblasti u Križevcima istaknulo da nema potrebe za osnivanjem Hrvatske pravoslavne crkve. ${ }^{156}$ Prema popisu koji je izradila Križevačka biskupija, 237 osoba iz Vojakovca i okolice je prekršteno na grkokatoličku vjeroispovijest do kraja travnja 1942. ${ }^{157}$ Slično je bilo i s naseljem Rovišće, gdje je župom upravljao Stanko Višošević iz Križevaca, a kasnije Tomo Severović i Spiridon Petranović. U parohiji Salnik (sela Salnik i Lipnica) u blizini Vrbovca na grkokatoličku vjeroispovijest prekrštene su 123 osobe u listopadu 1941, a u parohiji Hrvatska Kapela 1.200 osoba. ${ }^{158}$ U općini Vrbovec, pod koju je pripadala i parohija Salnik, 59 osoba je prekršteno na rimokatoličku vjeroispovijest do sredine 1942. godine. ${ }^{159}$

Na području kotara Novi Marof bilo je prekrštavanja s pravoslavne na starokatoličku vjeroispovijest. U selu Radoišće živjela je

nije bio pravi Hrvat. Da prekrštavanja na grkokatoličku vjeroispovijest u velikom broju slučajeva nisu pomagala, pokazuje i činjenica da su brojni novopečeni grkokatolici iz župe Prgomelje odvedeni u logor Jasenovac u noći između 9. i 10. listopada 1942. godine. U tom odvođenju pokupljeni su i stari grkokatolici. Razlozi njihovog odvođenja u logor navodno nisu bili ti što su po vjeroispovijesti bili prije pravoslavci koji su prekrš̌teni na grkokatoličku vjeroispovijest, već činjenice političke naravi, kako navodi Šimrak u svojem dopisu Alojziju Stepincu u kojem mu se žali na Miju Jurića (HDA, MPB NDH, kutija 75, 3607-B-1943). Detalje vidjeti i u: J. Krišto, Sukob simbola, Politika vjere i ideologije u Nezavisnoj Državi Hrvatskoj, Zagreb, 2001, str. 221-224. Ovdje Krišto donosi čitavo pismo iz kojeg je jasno vidljivo da Šimrak protestira zbog odvođenja njegovih starih i novih vjernika u koncentracione logore.

154 HDA, Državno ravnateljstvo za ponovu, vjerski odsjek, kutija 584, 159/1941.

155 HDA, MPB NDH, kutija 46, 7047-B-1942.

156 HDA, MPB NDH, kutija 45, 6340-B-1942.

157 HDA, MPB NDH, kutija 46, 7047-B-1942. Podatak da je crkva u Pobrđanima pokraj Vojakovca djelomično porušena iznosi Gabrijel Bukatko te je zatražio momentanu pomoć da bi se crkva uredila. (HDA, MPB NDH, kutija 53, 9282-B-1942).

158 HDA, MPB NDH, kutija 46, 7047-B-1942. Prema popisu koji je donijela Križevačka biskupija svega je 50 osoba iz Hrvatske Kapele prekršteno na grkokatoličku vjeroispovijest. Popis možda nije potpun (HDA, SDS RSUP SRH, 013.0.64, kopija dokumenta MPB NDH, kutija 50, 8964-B-1942). Iz općine Farkaševac kojoj je pripadala Hrvatska Kapela 401 pravoslavac je prekršten na rimokatoličku vjeroispovijest do lipnja 1942. Čak 1.027 osoba zatražilo je prekrštavanje na rimokatoličku vjeroispovijest, tako da podatak o 1.200 grkokatolika na tome području ne odgovara istini. (HDA, SDS RSUP SRH, 013.0.64, kopija dokumenta MPB NDH, kutija 9765-B-1942).

159 HDA, MPB NDH, kutija 47, 7384-B-1942. 
relativno mala pravoslavna zajednica. Čini se da je većina tamošnjih pravoslavnih porodica, njih 19, prekršteno na starokatoličku vjeroispovijest. Ostalih sedam obitelji koje su živjele razasute po čitavom kotaru Novi Marof, prekrštene su na rimokatoličku vjeroispovijest do 25. studenog 1941. godine. ${ }^{160}$

Kao i na garešničkom području, u okolici Križevaca postojala je, dakle, mala grkokatolička župa u Prgomeljama na temelju koje je Grkokatolička crkva pokušala dobiti jurisdikciju nad čitavom zonom od Bjelovara do Podravine. Većih je uspjeha u križevačkom kraju imala u potkalničkim selima oko Vojakovca, u okolici Svetog Ivana Žabna i u kraju između Svetog Ivana Zeline i Vrbovca. U selu Radoišće južno od Novog Marofa pravoslavni su svi prekršteni na starokatoličku vjeroispovijest. Čini se da im je u konkretnom slučaju svima bilo draže da budu prekršteni na bilo koju vjeroispovijest osim rimokatoličke. Činjenica jest da i prekrštavanja na rimokatoličku i grkokatoličku vjeroispovijest nisu mnogo pomagala bivšim pravoslavcima u njihovu položaju u NDH, budući da su ih ustaše ipak odvodili u koncentracione logore (iako pod drugim izgovorima), o čemu svjedoči i hapšenje bivših pravoslavaca u selima između Bjelovara i Križevaca u listopadu 1942.

\section{Podravina (Koprivnica, Ludbreg, Đurđevac)}

U Podravini su Srbi živjeli u najvećem broju slučajeva na obroncima Bilogore. I ondje je, kao i u ostalim dijelovima sjeverozapadne Hrvatske, bilo masovnih prekrštavanja na rimokatoličku i grkokatoličku vjeroispovijest. Koliko je vidljivo, prekrštavanja su iz početka bila pojedinačna. Tako su na području Sokolovca do sredine kolovoza 1941, kada je poduzeto i prisilno iseljavanje Srba iz kotara Koprivnica u Srbiju, na rimokatoličku vjeroispovijest prekrštene tek 24 osobe. ${ }^{161}$ Međutim, nešto kasnije se na istom području prijavilo oko 1.000 ljudi za prekrštavanje na rimokatoličku vjeroispovijest. Čini se da su istovremeno grkokatolički svećenici iz okolice Križevaca posjetili sela na sjevernim obroncima Bilogore i istočnim obroncima Kalnika i dijelili stanovništvu općine Sokolovac potvrde o prekrštavanju na grkokatoličku vjeroispovijest, što nisu imali pravo budući da na koprivničkom području nije bilo grkokatoličkih župa. ${ }^{162}$ Takvu su agitaciju izvršili više puta, a posebno na području Velikog Poganca, tako da je velik broj pravoslavaca u tome i okolnim selima odustao od prekrštavanja na rimokatoličku vjeroispovijest te su se odlučili da "prijeđu na grkokatoličku vjeroispovijest". Tada su se pojavile osobe koje su agitirale protiv prekrštavanja pravoslavaca na rimokatoličku, odnosno grkokatoličku vjeroispovijest, pa su čak i

160 HDA, Državno ravnateljstvo za ponovu, vjerski odsjek, kutija 584, 627/1941.

161 HDA, MPB NDH, kutija 5, 715-B-1941.

162 HDA, MPB NDH, kutija 18, 5592-B-1941. 
plašili stanovništvo da će nastradati kada se vrati "srpska vlast". ${ }^{163}$ U listopadu 1941. zabranjeno je bilo da pravoslavna sela u okolici Sokolovca "prijeđu na grkokatoličku vjeroispovijest", ${ }^{164}$ iako su se 9. listopada 1941. predstavnici parohija Velika Mučna, Lepavina, Gornje Sredice i Veliki Poganac prijavili kod katedralnog župnog ureda Svetog trojstva u Križevcima za prekrštavanje na grkokatoličku vjeroispovijest. Kao temelj prekrštavanja tih parohija na grkokatoličku vjeroispovijest dr Janko Simrak, katedralni administrator i grkokatolički župnik iz Križevaca, ističe da se područje Marčanske biskupije, u okviru koje se do sredine 18. stoljeća nalazila i Lepavina, "vazda protezalo na cijelom spomenutom teritoriju". ${ }^{165}$ Čini se da je, prema iskazu Janka Šimraka organima OZN-e, lokalni bilježnik iz Sokolovca prolazio po čitavoj sokolovačkoj općini i tražio da pravoslavni "ne prelaze na grkokatoličku vjeroispovijest, već na rimokatoličku". 166 Međutim, prema iskazima svjedoka s toga područja koje su dali u Komesarijatu za izbeglice i preseljenike u Beogradu, masovno je prekrštavanje pravoslavnih na grkokatoličku vjeroispovijest uslijedilo u travnju 1942. godine. O tome je iskaz dala Bogdana Milojević iz Velikog Poganca: "Tako je došao i mesec april 1942. godine, kada su Srbi dobili pozive od opštinske uprave, u kojima je stajalo da će svi ići na prisilan rad u Nemačku. Istodobno su u narod pušteni glasovi da neće ići na rad u Nemačku oni Srbi koji pređu na grčkokatoličku veru. $U$ isto vreme dobila je grčko-katolička biskupija u Križevcima generalnu dozvolu od Ministarstva bogoštovlja i nastave iz Zagreba da preuzme sve srpsko-pravoslavne crkve u onim krajevima, kao i manastir Lepavinu. Posle toga, grčko-katolička biskupija iz Križevaca poslala je u srpske parohije u Velikom Pogancu i Velikoj Mučni, sreza koprivničkog, te u Dugoj Reci i Bolfanu, sreza ludbreškog, po jednog svog sveštenika, koji je preuzeo crkve i tamo ostao kao mesni grčko-katolički sveštenik. Isto tako preuzeli su grčko-katolici i srpski manastir Lepavinu. Srpski narod se tome pokorio i prišao grčko-katoličkoj crkvi, gledajući u tome jedino moguće rešenje teške sudbine. Za župnika grčko-katoličke crkve u Velikom Pogancu došao je neki sveštenik prezimenom Jurista, koji je bio pobegao pred partizanima iz okoline Banja Luke." ${ }^{167}$ Iz dokumenata koji su dostupni u Hrvatskom državnom arhivu vidljivo je da je prekrštavanje pravoslavnih stanovnika iz parohija Velika Mučna i Veliki Poganac, njih 3.300 (1.500 iz Velike Mučne i 1.800 iz Velikog Poganca) obavio 18. siječnja 1942. grkokatolički župnik Mihajlo Jurista, kojemu je pročelnik Odjela za bogoštovlje Ministarstva pravosuđa i bogoštovlja dao grkokatoličku župu (nekadašnju pravoslavnu paro-

163 HDA, MPB NDH, kutija 18.

164 HDA, MPB NDH, kutija 18, 5590-B-1941.

165 HDA, MPB NDH, kutija 32, 2651-B-1942.

166 HDA, SDS RSUP SRH, 001.12, Iskaz Janka Šimraka, 12.

167 V. Đ. Đurić, Prekrštavanje Srba u Nezavisnoj Državi Hrvatskoj, Prilozi za istoriju genocida, Beograd, 1991, str. 169. 
hiju) u Velikoj Mučni s filijalom u Lepavini. ${ }^{168} \mathrm{Na}$ taj je način spašen manastir Lepavina, koji su ustaške vlasti tih dana namjeravale srušiti. ${ }^{169}$ U ožujku 1942. bivši pravoslavci iz općine Sokolovac dobili su pozive za odlazak na prisilan rad u Njemačku. Međutim, od toga in je posla zaštitila činjenica što su već prekršteni na grkokatoličku vjeroispovijest te su isticali da će se radije boriti protiv četnika u Bosni ili Rusa na strani Njemačke, nego li ići na prisilan rad, što su smatrali ponižavajućim poslom. Kotarska vlast u Koprivnici smatrala je da su prekrštavanja na grkokatoličku vjeroispovijest koje je provodio Jurista neispravna i da ih treba poništiti. ${ }^{170} \mathrm{U}$ Malom i Velikom Pogancu za župnika je postavljen Nenad Gavrilović, Srbin, rodom iz Gline koji je prekršten na grkokatoličku vjeroispovijest. Gavrilović je preuzeo i bivšu parohiju u Bolfanu s filijalom u Čukovcu, ali je taj posao ubrzo povjeren župniku iz Plavšinaca Feliksu Bilenikiju. Gavrilovića su likvidirali partizani 13. prosinca 1944. godine. ${ }^{171} \mathrm{Gr}$ kokatolički svećenici suočavali su se s otvorenim neprijateljstvom lokalnih vlasti i na koprivničkom području. Čini se da su početkom 1942. dvojica grkokatoličkih svećenika, Nenad Gavrilović i Mihajlo Jurista, došli na poziv vjernika u parohiju Plavšinçi da održe službu i da obave blagoslov kuća. Prema iskazu Janka Šimraka organima OZN-e, čim su stigli u selo i došli u doticaj s ljudima, napao ih je ustaša Marcapan i otpremio ih u zatvor u Koprivnicu. ${ }^{172}$ Otvoreno neprijateljstvo prema Grkokatoličkoj crkvi bilo je osobito ispoljeno kod lokalnih vlasti u kotarima Koprivnica i Čazma. Međutim, prema dokumentaciji sačuvanoj u fondu Ministarstva pravosuđa i bogoštovlja, neprijateljstvo je postojalo i kod lokalnih vlasti u kotaru Garešnica. Prema iskazu Drage Jagodića iz Plavšinca, u mjesto je kasnije došao grkokatolički svećenik koji je držao službu u nekadašnjoj pravoslavnoj crkvi, a lokalni Srbi imali su dužnost da svećeniku daju mast, krumpir, žito, brašno i sve ostale potrepštine. ${ }^{173}$ Prema iskazu Janka Šimraka organima OZN-e, formalnosti prekrštavanja na grkokatoličku vjeroispovijest na toj parohiji nisu izvršene, a broj vjernika je iznosio $600 .{ }^{174}$

168 HDA, MPB NDH, kutija 33, 3054-B-1942. Prema izvještaju Općinskog poglavarstva Sokolovac od 142 doma u Velikom Pogancu 138 ih je prekršteno na grkokatoličku vjeroispovijest, a četiri su bila rimokatoličke vjeroispovijesti. (HDA, MPB NDH, kutija 65, 347-B-1942).

169 S. Bunjevac, „Izvorni dokumenti OZNE o biskupu dr. Janku Šimraku i ,prekrštavanju' Srba u NDH", Glas koncila, 21 (1613), 22. svibnja 2005.

170 HDA, MPB NDH, kutija 38, 4401-B-1942.

171 S. Bunjevac, „Izvorni dokumenti OZNE o biskupu dr. Janku Šimraku i , prekrštavanju' Srba u NDH", Glas koncila, 22 (1614), 29. svibnja 2005.

172 S. Bunjevac, „Izvorni dokumenti OZNE o biskupu dr. Janku Šimraku i, prekrštavanju' Srba u NDH", Glas koncila, 19 (1611), 8. svibnja 2005.

173 V. Đ. Đurić, Prekrštavanje Srba u Nezavisnoj Državi Hrvatskoj, Prilozi za istoriju genocida, Beograd, 1991, str. 169-170.

174 S. Bunjevac, "Izvorni dokumenti OZNE o biskupu dr. Janku Šimraku i,prekrštavanju’ Srba u NDH", Glas koncila, 21 (1613), 22. svibnja 2005. 
Do 2. prosinca 1941. od 434 pravoslavaca na području općine Ludbreg svega ih je 38 prekršteno na rimokatoličku vjeroispovijest, dok in je 174 zatražilo "prijelaz", ${ }^{175}$ a do kraja prosinca 1941. na području kotara Đurđevac od 430 pravoslavnih 353 in nije zatražilo "prijelaz", 54 ih je prekršteno na rimokatoličku vjeroispovijest i 23 ih je "najavilo prijelaz na rimokatoličku vjeroispovijest". ${ }^{176}$ Broj onih koji su prekršteni na području kotara Đurđevac povećao se na 69 do 17. ožujka 1942. Do toga datuma prekrštavanje je najavilo još 87 pravoslavaca, a nije ih prekršteno $280 .{ }^{177}$ Razlozi relativno malom broju onih koji su se prijavljivali za prekrštavanje na području Podravine bili su, prema izvještaju općinskog poglavarstva u Ludbregu, "što (prekrštavanjem na rimokatoličku vjeroispovijest - op. a.) nemaju nikakove beneficije kao i ostali, a veći broj izjavljuju da ionako ostaju ono što jesu, tj. Srbi". 178 Nakon prisilnog iseljavanja 64 pravoslavne obitelji s područja općine Rasinja u općini je ostalo još 254 pravoslavca. Od toga ih je svega pet najavilo da će se prekrstiti, dok ostali to nisu učinili. Evidentno je da su se nakon prisilnog iseljavanja Srba s područja Podravine preostali Srbi vrlo teško odlučivali za prekrštavanje, nesigurni u to da će im ti "prijelazi" uopće pomoći. ${ }^{179} \mathrm{U}$ ludbreškom kraju pravoslavci su u ožujku 1942. godine zatražili da se crkva u Dugoj Rijeci preuredi u rimokatoličku bogomolju. ${ }^{180}$ Interesantan je odgovor općinskog poglavarstva Ludbreg u kojem se navodi da niti jedna od 300 osoba iz Male Rijeke, Duge Rijeke i Ludbreškog Ivanca do srpnja 1942. nije prekrštena na rimokatoličku vjeroispovijest, pa da razloga za preuređenje crkve u rimokatoličku nema. Međutim, u listopadu 1942. već je u Dugoj Rijeci bilo 168 grkokatolika i 264 rimokatolika. ${ }^{181}$

U Podravini je, dakle, Grkokatolička crkva imala više uspjeha. Ondje su evidentno sela na obroncima Kalnika i Bilogore gotovo u potpunosti prekrštena s pravoslavne na grkokatoličku vjeroispovijest. Razlozi tome leže u pojačanoj agitaciji grkokatoličkog svećenstva na tome području i u ulozi Grkokatoličke crkve u spašavanju manastira Lepavina od uništavanja. Usprkos tome, kotarske vlasti iz Koprivnice bile su vrlo neraspoložene prema grkokatolicima i prekrštavanjima pravoslavnih vjernika na grkokatoličku vjeroispovijest te su, kada god je to bilo moguće, osporavale njihova prekrštavanja tvrdeći da ona nisu učinjena po zakonu.

175 HDA, Državno ravnateljstvo za ponovu, vjerski odsjek, kutija 584, 371/1941.

176 HDA, MPB NDH, kutija 26, 573-B-1942.

177 HDA, MPB NDH, kutija 28, 1269-B-1942.

178 HDA, Državno ravnateljstvo za ponovu, vjerski odsjek, kutija 584, 547/1941.

179 HDA, Državno ravnateljstvo za ponovu, vjerski odsjek, kutija 584, 686/1941.

180 HDA, MPB NDH, kutija 50, 8964-B-1942.

181 HDA, MPB NDH, kutija 65, 347-B-1943. 


\section{Zagreb}

Zato da bi izbjegli progon iz grada Zagreba, pravoslavni su masovno pristajali na prekrštavanje na rimokatoličku vjeroispovijest. Manji je broj onih koji su prekršteni na grkokatoličku vjeroispovijest, a još manji broj onih koji su prekršteni na starokatoličku ili evangeličku vjeroispovijest, odnosno na islam. Prema evidenciji "vjerozakonskih prijelaza" samo je na području Zagreba između 1941. i 1945. izvršeno je 9.764 "vjerozakonskih prijelaza" (od toga 9.408 između 1941. i 1943, 275 u 1944. i 81 u 1945. godini). ${ }^{182}$ Za 7.070 prekrštenih su nam sačuvana imena i prezimena. Koliko sam ih ja izbrojio, od toga je bilo 3.385 prekrštavanja s "grčko-iztočne", odnosno "pravoslavne", "bugarsko-pravoslavne", "pravoslavno-istočne", odnosno "rusko-pravoslavne" vjeroispovijesti na neku drugu vjeroispovijest. Od toga ih je svega 24 bilo u 1944. i osam u 1945. dok su između 1941. i 1943. izvršena 3.353 "vjerska prijelaza". Prekrštavanja s rusko-pravoslavne i bugarsko-pravoslavne vjeroispovijesti dosežu brojku od svega dvadesetak osoba. ${ }^{183} \mathrm{Na}$ području kotara Zagreb do travnja 1942. bilo je 159 prekrštavanja s pravoslavne na rimokatoličku vjeroispovijest. ${ }^{184}$

\section{Zaključak}

Osim sporadičnog i mlakog spočitavanja, Katolička crkva nije ustaškom režimu osporavala pravo da u njeno ime najavljuje, propagira i politički manipulira konverzijom kao činom eminentno duhovničkog karaktera, nego je poslušno izvršavala političku volju režima kao da je njena, u duhu nadbiskupovog naputka o "uzvišenom radu oko čuvanja i unapređenja NDH". Pavelić 3. svibnja 1941. donosi Zakonsku odredbu o prijelazu s jedne vjere na drugu, koja je usmjerena na sprečavanje prijelaza bez kontrole državnih organa: "Za valjanost prelaza potrebno je, da stranka, koja mijenja vjeru podnese pismenu prijavu upravnoj vlasti (...) i da dobije potvrdu o toj svojoj prijavi". Uredba je ukinula i sve dotadašnje zakonske propise o prijelazu iz jedne vjere u drugu, a to znači i vjerske propise, što je dodatno precizirano povjerljivim dopisom Ministarstva bogoštovlja i nastave katoličkim biskupskim ordinarijatima od 14. srpnja 1941,185 te Uputom istog ministarstva od 27. svibnja $1941 .{ }^{186}$ Iako Nadbiskupski duhovni stol u Zagrebu 8. svibnja reagira na taj pokušaj državne vlasti da se Crkvu instrumentalizira,

182 Prva knjiga "vjerozakonskih prijelazaka" u Zagrebu u kojoj se nalazilo upisano 2.694 prekrštenih 1941. nije sačuvana. Sačuvani su nam redni brojevi od 2.695. nadalje.

183 HR-DAZG - 24 (Hrvatska, Državni arhiv u Zagrebu) GPZ (Gradsko poglavarstvo Zagreb), politički odsjek, Polit 14, Iskaz vjerozakonskih prijelaza (1941. -)

184 HDA, MPB NDH, kutija 40, 5039-B-1942.

185 J. Krišto, Sukob simbola. Politika, vjere i ideologije u Nezavisnoj Državi Hrvatskoj, Zagreb, 2001, str. 177-178.

186 Ibid., str. 176. 
a Crkva iskazuje i neslaganje s dopisima Ministarstva bogoštovlja i nastave da se pravoslavcima ne smije dopustiti da prelaze na grkokatoličku vjeroispovijest jer se "grkokatolički obred smatra ravnopravnim s rimskim obredom", kao i da se u rimokatoličku vjeroispovijest ne trebaju primati pravoslavni svećenici, učitelji, inteligencija, trgovci i obrtnici jer bi se to "protivilo duhu, a i zadaći katoličke crkve", ${ }^{187}$ praksa masovnog prekrštavanja Srba koja je usljedila pokazuje da su te rezerve Crkve bile deklaratorne naravi.

Uz ubijanje i prisilno iseljavanje, jedan od modula "rješavanja srpskog pitanja" bila su, dakle, prekrštavanja Srba sa pravoslavne na rimokatoličku ili grkokatoličku vjeroispovijest. Prekrštavanja su imala za cilj asimilaciju pravoslavnog stanovništva, odnosno, kako su ustaše govorili, njihovo "vraćanje vjeri otaca". Prekrštavanja su bila najmasovnija u drugoj polovici 1941. i u prvoj polovici 1942. Do početka 1942, u jedva šest mjeseci, s pravoslavne na rimokatoličku vjeroispovijest prekršteno je u NDH oko 100.000 Srba. ${ }^{188}$ Formiranjem Hrvatske pravoslavne crkve 1942. godine broj prekrštavanja je naglo pao. Motivi njihova pristanka na prekrštavanje bili su strah pred fizičkom likvidacijom ili prisilnim iseljavanjem. Prekrštavanje se nije temeljilo na dobrovoljnosti i samosvjesti, nego je prvenstveno bilo motivirano spašavanjem imovine i vlastitih života. Međutim, ni prekrštavanja nisu uvijek garantirali sigurnost "prijelaznicima". U više slučajeva "prijelaznici" su odvođeni u logore ili likvidirani u ustaškim odmazdama, šikanirani ili prisilno iseljavani iz NDH. One koji su prekršteni na neku drugu vjeroispovijest rijetko kada su zaštićivale lokalne vlasti, a nešto češće lokalno svećenstvo, koje se povremeno zalagalo za "prijelaznike". Prekrštavanje je bilo "najuspješnije" u krajevima gdje su Srbi bili u manjini. U sjeverozapadnoj Hrvatskoj prekrštavanja su po brojnosti bila najmasovnija u bjelovarskom i koprivničkom kraju, zatim na području Garešnice, oko Križevaca, Hrvatske Kostajnice, Petrinje i Gline te u okolici Karlovca, Slunja, Vrbovskog i Ogulina. Broj prekrštenih teško je točno utvrditi, ali prema postojećim podacima treba računati da ih je na tim područjima današnje Hrvatske od ljeta 1941. do ljeta 1942. bilo ukupno blizu 50.000 ili otprilike pola od ukupnog broja prekrštenih u NDH. Kako je pravoslavnih u tom području u to vrijeme bilo 250.000 do 300.000 , udio prekrštenih je bio 16-20\%. Za cijelu NDH u korelaciji su brojke 1.800 .000 pravoslavnih stanovnika i 100.000 prekrštenih $(6 \%)$.

Osvrnemo li se na onu strateški planiranu "trotrećinsku formulu" ustaškog "konačnog rješenja srpskog pitanja" (trećinu ubiti, trećinu iseliti, trećinu prekrstiti) i provjerimo kako je ona realizirana u prvoj godini ustaške vlasti, rezultat je sljedeći: ubijeno je ne manje

187 Ibid., str. $172-175$.

188 N. Bartulin, "Ideologija nacije i rase: ustaški režim i politika prema Srbima u Nezavisnoj Državi Hrvatskoj 1941.-1945.", Radovi Zavoda za hrvatsku povijest, vol. 39 (2007), str. 230. 
od 24.854 Srba ${ }^{189}$ civila, terorom ih je protjerano i u Srbiju organizirano prisilno iseljeno (do ožujka 1942) ukupno $80.113,{ }^{190}$ a prekrštavanjem je otpočeo proces asimilacije njih oko 100.000. Sve to u manje od godinu dana.

\title{
Summary
}

Filip Škiljan, Ph. D.

\section{Forced Conversion of Serbs on the Territory of Northwest Croatia in 1941 and $1942^{191}$}

\author{
Key words: ISC (NDH), Serbs, forced conversion, Ustaše, \\ legislation, propaganda.
}

Except for sporadic and mild rapprochements, the Catholic Church did not contest the right of the Ustaša regime to announce, propagandize and politically manipulate in her name with conversion which is an act of eminent spiritual character, but the Church obediently executed the political will of the regime as if it had been her own, in the spirit of the archbishop's instructions "on the sublime

189 I. Graovac, D. Cvetković, Ljudski gubici Hrvatske 1941.-1945. godine; pitanja primjeri, rezultati..., Zagreb, 2005, str. 59, 60.

190 AS, Komesarijat za izbeglice i preseljenike, G. 2, F. 2.

191 Different terms have been used in historiography to refer to the Serbs' change of faith in the Independent State of Croatia and their admission to Roman Catholic or Greek Catholic denominations. Apart from the term "Christianize" which is completely incorrect because the Orthodox Serbs were already baptized Christians, the most often used terms are "Catholization", "change of religious affiliation", "religious reaffiliation" and "conversion". The first term is openly biased and burdened by historical residue (missionary Catholization of the pagans), the second refers to any change of religion and creed (there is no distinction between "changing religious affiliation" for example of Jews and "changing of religious affiliation" of Serbs, the last two terms were used by the Ustašas themselves and the Roman Catholic/Greek Catholic clergy who reduced the act of renouncing the Orthodox faith by undergoing an initiation rite of admission to the Catholic faith to a politically neutral, technical term lacking connotations. The term "religious reaffiliation" also implies voluntariness and an act that is not forced on somebody, however these attributes cannot be realistic terms for most of the renouncements of the old faith of the Serbs in ISC, which was especially true for collective conversions. In addition, these conversions were not autonomous acts harmonized with the conscience of the individual where he/she truly, cognitively accepts another religious creed but an extracted, dubious, ritualistic act that was mediated and which the terms "religious reafilliation" and "conversion" hide in a demagogic and defensive way. The term "forced conversion " apart from being colloquially used, is the term which clearly denotes what happened to the Serbs in ISC in WW II: implies the genocidal intent and connection of the Catholic Church and regime. Regardless of the fact that the "forced conversion" was a "substitute" and "milder" destiny in comparison to physical extermination, it was genocidal lever, a shameful practice with honorable exceptions... Nevenko Bartulin, "Ideologija nacije i rase: ustaški režim i politika prema Srbima u Nezavisnoj Državi Hrvatskoj 1941.-1945.", Radovi Zavoda za hrvatsku povijest, vol. 39 (2007), pp. 228-229. 
work for the protection and advancement of Independent State of Croatia (ISC)". Pavelić issued a Legislative decree on conversion from one faith to another on $3^{\text {rd }}$ of May 1941 whose aim was to stop the conversion from one faith to the other without government control: "For the conversion to be valid it is necessary that the individual that is changing his/her faith submit a written application to the governing body (...) and obtain a confirmation of the application". The decree repealed all the existing laws on conversion from one faith to another including the religious regulations, which was made additionally clear by a classified letter the Ministry of Religion and Education sent to Catholic Bishop ordinatori on $14^{\text {th }}$ May $1941^{192}$ and by the Instructions sent by the same Ministry on $27^{\text {th }}$ May. ${ }^{193}$ Although the Archbishops' Advisory Board in Zagreb reacted on $8^{\text {th }}$ of May to this attempt of the state to instrumentalize the Church and the Church expressed disagreement with the letters sent by the Ministry of Religion and Education that stated that the Orthodox should not be allowed to convert to Greek-Catholic denomination because "the Greek-Catholic rite is considered equal to the Roman rite" and that Orthodox priests, teachers, intelligentsia, merchants and craftsmen should not be accepted into the Roman Catholic faith because that would be "contrary to the spirit and aims of the Catholic Church", 194 however the practice of mass forced conversion of Serbs that followed showed that the expressed reservations of the church were only of declarative nature.

Together with extermination and enforced expulsion, one of the modules for "the solution of the Serbian question" was forced conversion of Serbs from the Orthodox faith into Roman Catholic or Greek Catholic faith. The aim of this forceful conversion was to assimilate the Orthodox population, that is, as the Ustaše used to say, "to return them to the faith of their fathers". The forced conversions were most massive in the second half of 1941 and first part of 1942. Until the beginning of 1942, in just six months, about 100,000 Serbs were forcefully converted into the Roman Catholic faith. ${ }^{195}$ When the Croatian Orthodox Church was formed in 1942 the number of conversions suddenly decreased. The motives of the Serbs to accept forced conversion were fear in the face of a physical extermination or forced emigration. Thus, conversion was not based on voluntary and self-consciousness change from one Christian faith to another

192 Nevenko Bartulin, "Ideologija nacije i rase: ustaški režim i politika prema Srbima u Nezavisnoj Državi Hrvatskoj 1941.-1945.", Radovi Zavoda za hrvatsku povijest, vol. 39 (2007), pp. 228-229.

193 A large number of Orthodox priests was murdered in the pogroms that followed the expulsion or were murdered at the same time. (See in: Veljko $Đ$, Đurić, Ustaše i pravoslavlje, Beograd, 1989, pp. 106-117; Spomenica pravoslavnog sveštenstva žrtava fašističkog terora, Beograd, 1960).

194 Narodne novine, 4. svibnja 1941.

195 Marco Aurelio Rivelli, Nadbiskup genocida, Nikšić, 1999, p. 40. 
but was primarily motivated by a will to save one's life and property. However, even this did not always guarantee safety to those who "converted". In many cases "the people who converted" were taken to camps or murdered in Ustaša's reprisals, harassed or forcefully expelled from ISC. Thus, those who converted under pressure into another faith were rarely protected by the local officials, and a little more often by the local priest who from time to time interceded in favor of them. The forced conversions were "most successful" in areas where the Serbs were a minority. The forced conversions were most numerous in the northwest parts of Croatia in the region of Bjelovar and Koprivnica, then in region of Garešnica, in the vicinity of Križevac, Hrvatska Kostajnica, Petrinja and Glina, as well as Karlovac, Slunj, Vrbovska and Ogulin. It is difficult to establish the exact number of forcibly converted Serbs, but according to the existing data it should be estimated that on the territory of today's Croatia from the summer of 1941 until the summer of 1942 there were altogether nearly 50,000 forced conversions or circa half of the total number of converted Serbs in ISC. As the Orthodox population numbered in that region between 250, 000 to 300,000 inhabitants the portion of Serbs converted by force was about $16-20 \%$. The coloration for the whole of ISC statistically was $1,800,000$ Orthodox population and 100,000 converted $(6 \%)$.

If we look at the Ustaša's strategically planned "three thirds formula" for the "final solution of the Serbian question" (one third should be exterminated, one third expelled, one third converted) and if we examine how it was realized in the first year of the Ustaša rule, the result is the following: no less than 24,854 Serb $^{196}$ civilians were killed, forced to leave by terror or expelled to Serbia in an organized way that is a total of $80,113^{197}$ people (up to March 1942) while the process of assimilation started with the forced conversion of 100,000 Serbs. All that was done in less than a year.

196 Narodne novine, 4. svibnja 1941.

197 Katolički list, br. 19, 15. svibnja 1941. 